IZA DP No. 8248

Public Opinion on Immigration:

Has the Recession Changed Minds?

Timothy J. Hatton

June 2014 


\title{
Public Opinion on Immigration: Has the Recession Changed Minds?
}

\author{
Timothy J. Hatton \\ University of Essex, \\ Australian National University and IZA
}

Discussion Paper No. 8248

June 2014

IZA
P.O. Box 7240
53072 Bonn
Germany

Phone: +49-228-3894-0

Fax: +49-228-3894-180

E-mail: iza@iza.org

Any opinions expressed here are those of the author(s) and not those of IZA. Research published in this series may include views on policy, but the institute itself takes no institutional policy positions. The IZA research network is committed to the IZA Guiding Principles of Research Integrity.

The Institute for the Study of Labor (IZA) in Bonn is a local and virtual international research center and a place of communication between science, politics and business. IZA is an independent nonprofit organization supported by Deutsche Post Foundation. The center is associated with the University of Bonn and offers a stimulating research environment through its international network, workshops and conferences, data service, project support, research visits and doctoral program. IZA engages in (i) original and internationally competitive research in all fields of labor economics, (ii) development of policy concepts, and (iii) dissemination of research results and concepts to the interested public.

IZA Discussion Papers often represent preliminary work and are circulated to encourage discussion. Citation of such a paper should account for its provisional character. A revised version may be available directly from the author. 


\section{ABSTRACT \\ Public Opinion on Immigration: Has the Recession Changed Minds?*}

It is widely believed that the current recession has soured public attitudes towards immigration. But most existing studies are cross sectional and can shed little light on the economy-wide forces that shift public opinion on immigration. In this paper I use the six rounds of the European Social Survey (2002-2012) to test the effects of economic shocks on immigration opinion for 20 countries. The recession that began in 2008 provides a useful test because its severity varied so widely across Europe. For Europe as a whole the shifts in average opinion have been remarkably mild. But trends in opinion have varied across countries, especially in the responses to a question on whether immigrants are good or bad for the economy. At the country level, pro-immigration opinion is negatively related to the share of immigrants in the population and to the share social benefits in GDP, but only weakly to unemployment. These effects differ somewhat across responses to different questions relating to immigration policy and to the desirability of immigrants. The recession also influenced other attitudes and traits that are sometimes linked to opinion on immigration.

JEL Classification: D72, F22, J61

Keywords: public opinion, immigration attitudes, immigration policy

Corresponding author:

Tim Hatton

Department of Economics

University of Essex

Colchester CO4 3SQ

United Kingdom

E-mail: hatton@essex.ac.uk

\footnotetext{
* I am grateful Patrick Nolen and Marco Francesconi for useful suggestions and to participants at an Essex seminar and at an ISER/CReAM Workshop on Immigration: Economic Impact, and Social Attitudes. I am also indebted to Eirik B. Stavestrand of the ESS Data team at NSD Bergen for generous help with combining ESS datasets.
} 


\section{Introduction}

It is widely believed that in severe recessions public opinion on immigration becomes more negative. When labour markets become slack, concerns about immigrants' competition for jobs increase. At times when public budgets come under pressure concerns about the fiscal impact also intensify. Little surprise then that politicians ramp up their anti-immigration rhetoric a bid to gain favour with voters who they believe are shifting in that direction. In the UK for example, party leaders have tried to trump each other with tougher immigration policies aimed at mitigating job market competition and limiting immigrants' access to social benefits. The recent electoral success of the UK Independence Party has reinforced that trend. Elsewhere, the French President and the German Chancellor have similarly expressed concerns about immigrants' access to social security benefits. In Austria, the Netherlands, and across Scandinavia politicians have bowed to the increasing influence of right wing populist parties with anti-immigration platforms. ${ }^{1}$ Yet while the recession seems to have provided a justification for pandering to latent anti-immigration sentiment, it is far from clear how far average public opinion has shifted in that direction, or exactly why.

This paper investigates attitudes towards immigrants and immigration before and after the global financial crisis using the six waves of the European Social Survey (ESS). The ESS is a repeated cross-section survey that has been conducted on a biennial basis from 2002 to 2012 and so it includes years before and after the global financial crisis. As the crisis has affected European countries very differently, it also provides a sharp contrast in economic conditions before and after the crisis. It therefore offers a unique opportunity to assess the effects of economy-wide conditions on opinion towards immigration. The ESS data show that, on average across Europe, the change in immigration opinion has been surprisingly modest. But the trends have been more negative in the countries most affected by the recession and somewhat stronger for the responses to questions that are more closely related to the economic benefit of immigration.

\footnotetext{
${ }^{1}$ According to a Guardian headline (15/11/13): "The rise of far right parties across Europe is a chilling echo of the 1930s."
} 
The literature on immigration opinion has focused on the explaining differences across individuals according to their observable characteristics and attitudinal traits. The results are interpreted as reflecting economic and cultural concerns and there has been a vigorous debate on how far these reflect individual self-interest or wider sociotropic concerns. This cross-sectional literature has focused on the individual-level determinants of opinion and typically on characteristics that change only slowly. Despite extensive commentary about the overall trends in immigration opinion, the effects of economy-wide developments have rarely been identified. The few papers that have examined changes over time suggest that these have little to do with composition but largely reflect across-the-board shifts in opinion. In this paper I first use separate regressions for each country to adjust for demographic composition. Then the composition-adjusted period effects are used to examine country-level economic influences on average opinion in a panel of 20 countries over the six ESS rounds between 2002 and 2012.

The results at the second stage indicate that the two most influential variables shifting public opinion are the share of immigrants in the population and the share of social benefits in GDP. The latter is strongly correlated with increasing budget deficits in those countries that were worst hit by the recession. By contrast the unemployment rate matters only for responses to the question on whether immigrants are good for the economy. These country-level effects are much the same across different demographic groups by education, age and sex. Shifts in opinion on immigration are associated with shifts in other attitudes and traits, most notably trust in others and political attitudes. Some of the recession's impact on immigration opinion is associated with declines in the trust of politicians and dissatisfaction with the performance of governments.

\section{Analysing public opinion}

There is now a substantial literature that analyses the responses to a variety of questions about immigrants and immigration. Almost all of this analysis has been cross-sectional and the objective has been to tease out the perceived economic, social and cultural threats (or opportunities) that underlie public attitudes to immigration. Using a variety of microdatasets, for one or many countries, these studies have identified some key empirical regularities. Yet there remain significant differences both in the specifications used and in 
the interpretations placed on the results (see Ceobanu and Escandell 2010; Hainmueller and Hopkins 2014). It is important to stress that these studies focus almost entirely on what types of people are against immigration rather than on what determines changes in opinion.

The most important finding in cross-sectional studies is that those with higher education levels have more positive attitudes towards immigrants and are more likely to favour permissive immigration policies. In their study of opinion in the United States, Scheve and Slaughter (2001) conclude that this reflects the greater labour market competition faced by low skilled workers-the so-called factor proportions approach. Other studies support this view, with findings that the education effect is stronger for workers in occupations most exposed to immigrant competition (Dancygier and Donnelly 2013; Mahlotra et al. 2013) and for countries with low average skill levels (Mayda 2006; O'Rourke and Sinnott, 2006). An alternative interpretation of the education effect is that those with higher levels of education are more tolerant towards minorities and more positive about ethnic and cultural diversity. Hainmueller and Hiscox $(2007,2010)$ argue that labour market competition is not a convincing explanation of the education effect because high-skilled and low-skilled natives exhibit equally negative opinions about low-skilled immigration.

Several studies focus on concerns about the fiscal costs of immigration. This could be due either to the threat of immigrant competition for a fixed supply of welfare benefits for those at the bottom of the income distribution or because of the tax implications of immigrantinduced expansion of the welfare system for those further up. Using cross country data Facchini and Mayda (2009, 2012) find that, controlling for education, attitudes to immigration are negatively related to income, reflecting the dominance of concerns about the tax implications of immigrant welfare dependency. This helps to explain why attitudes are not always more positive among those higher up the scale of skill, education and income. This finding seems to contrast with the fact that the net fiscal contribution of immigrants is often positive. But Boeri (2010) finds some evidence that, across European countries, actual and perceived fiscal burdens are correlated and that higher fiscal burdens are associated with more negative opinion. Similarly, looking across US states Hanson et al. (2007) find that higher exposure to fiscal pressures reduces support for freer immigration policies, especially among college graduates. 
Despite the emphasis on economic determinants, a range of studies, particularly those in political science, argue that social and cultural determinants are more important (e.g. Citrin et al. 1997; Rustenbach 2010; Manevska and Achterberg 2013). They focus on authoritarian and ethnocentric attitudes that translate into views that range from nationalism and patriotism on one hand to racism and xenophobia on the other. ${ }^{2}$ One recurrent finding is that attitudes are more negative towards non-white immigrants and/or those with different languages, cultures and religions. Perceived cultural threats are inferred from the influence on immigration preferences of responses to questions on national identity and preserving national culture, attitudes towards safety and security, feelings of alienation, and positioning on the political spectrum. But unobserved heterogeneity across individuals is likely to mean that such attitudinal variables will be endogenously correlated with attitudes towards immigration. Nevertheless, using latent factor analysis on the ESS 2002, Card et al. (2012) distinguish between concerns about jobs and taxes and those related to cultural and social threats. They find that cultural and social threats are 2-5 times as important in explaining the variation in attitudes as economic concerns.

It has become increasingly clear that immigration preferences largely reflect sociotropic concerns rather than individual self-interest. Thus the focus is on the social or economic group that the individual identifies with rather than his or her personal welfare. ${ }^{3}$ Such concerns could be at a variety of levels: ethnicity, social class, industry, locality, or the nation as a whole (e.g. Dustmann and Preston 2001, 2007; Ford 2011; Dancygier and Donnelly 2013; Mahlotra et al. 2013; Markaki and Longhi, 2013). Some of these effects might be associated with personal characteristics or with other attributes, but others may not. Concerns about society at large or about the national economy may change as conditions evolve and may not be exclusive to individuals with particular characteristics. Some studies have examined such concerns directly by including as explanatory variables attitudes or expectations about the economy or society at large (e.g. Citrin et al. 1997; Hericourt and Spielvogel 2012). But, again, such individual-level evaluations are likely to be endogenous. Interestingly, in experimental work, Sniderman et al. (2004), find that negative

\footnotetext{
${ }^{2}$ These attitudes are often linked with support for far-right populist political parties (Ivarsflaten 2005; Mudde 2007, Ch.9; Lucassen and Lubbers 2012).

${ }^{3}$ Residents with ethnic minority backgrounds provide a good example: they are often strongly pro-immigration even though they are the group most likely to compete for jobs with new immigrants.
} 
shocks, rather than 'galvanizing' those who are initially predisposed against immigration, have the effect of 'mobilising' opinion across a broad range of individuals (see also Rydgren 2008). In that case an economy-wide recession should shift opinion across-the-boardsomething that will be investigated further below.

Although it seems likely that macroeconomic shocks will influence average opinion on immigration the existing evidence is remarkably thin. Multilevel cross-sectional studies have found mixed, mainly weak and sometimes perverse results from national-level variables (e.g. Lahav 2004; Sides and Citrin 2007; Semyonov et al. 2008; Rustenbach 2010). The variables most often included are the share of immigrants in the population, the unemployment rate and GDP per capita. ${ }^{4}$ Using ESS data, Sides and Citrin (2007, p. 477) concluded that "variation across countries in both the level and the predictors of opposition to immigration are mostly unrelated to contextual factors cited in previous research, notably the amount of immigration in to a country and the overall state of its economy." But, as countries differ in a wide variety of ways, it is hardly surprising that such studies fail to identify these effects in the cross section. The effects of macro-level variables can only be credibly identified if we focus on changes over time. ${ }^{5}$

A number of studies have focused on the time dimension for individual countries. For Canada in 1987-2008, Wilkes and Corrigall-Brown (2011) found that current macroeconomic conditions, as reflected by the unemployment rate, dominate composition and cohort effects on opinion towards immigrants. For Germany in 1980-2000, Coenders and Scheepers (2008) found negative effects on opinion for the unemployment rate and the share of nonEU immigrants in changes but not in levels. Recent studies that span the global financial crisis for Ireland (Denny and Ó Gráda 2013) and the United States (Goldstein and Peters 2014; Creighton et al. 2014) identify shifts in opinion without linking them to specific macro variables. These studies suggest that economy wide variables might have stronger effects than are observed in the cross section but such effects are hard to unpack for one country alone.

\footnotetext{
${ }^{4}$ Unemployment often gives the wrong sign, e.g. Sides and Citrin (2007), Rustenbach (2010).

${ }^{5}$ Diversity in country experience is also important; using the first three waves of the ESS, that preceded the global financial crisis, Meuleman et al. (2009) obtained results consistent with, but much weaker than, those reported here.
} 


\section{Opinion on Immigration in the European Social Survey}

The data analysed here are from European Social Survey, of which there have been six biennial rounds from 2002 to 2012. This is a repeated cross-sectional survey, not a panel. The first round included a special module with a wide range of questions about immigration, and this has been widely analysed. Six of these questions were incorporated into the core and were repeated in subsequent rounds. The cumulative dataset provides a unique opportunity to analyse immigration opinion over a decade that embraces the socioeconomic turbulence brought on by the global financial crisis. Although the country coverage has expanded over time, not all countries are present in every round since first appearance. Here I select the 20 countries that are present in at least four rounds, with at least one post-crisis round (2010 or 2012). ${ }^{6}$

Three of the six questions relate to preferences over the number of immigrants that should be admitted while the other three relate to their perceived impact on the host country. These questions, and their categorization, are as follows:

- To what extent do you think [country] should allow people of the same race or ethnic group as most [country] people to come and live here? (many/some/a few/none)

- How about people of a different race or ethnic group from most [country] people? (many/some/a few/none).

- How about people from the poorer countries outside Europe? (many/some/a few/none).

- Would you say it is generally bad or good for [country]'s economy that people come to live here from other countries? (range: $0=$ bad $\rightarrow 10=$ good).

- Would you say that [country]'s cultural life is generally undermined or enriched by people coming to live here from other countries? (range: $0=$ undermined $\rightarrow 10=$ enriched).

- Is [country] made a worse or a better place to live by people coming to live here from other countries? (range: $0=$ worse $\rightarrow 10=$ better).

\footnotetext{
${ }^{6}$ The ESS uses face-to-face interviews. Using experiments on the ESS with alternative interview modes, Jäckle et al. (2010) find that telephone interviewees are on average less anti-immigration but that this the difference does not significantly change the coefficients on a set of explanatory variables.
} 
These responses are expressed as scores so that higher numbers represent more proimmigrant attitudes. For the fourth to sixth questions the central (neutral) value is 5 . The first three questions are given values $2,4,6,8$, where 2 is 'none' and 8 is 'many', so that they have the same central value and similar variances to the other questions.

The average scores are shown in Table 1, by country and by year, using the country-specific weights. As is well known, across a variety of different questions, attitudes are broadly neutral on average. They are slightly more negative towards admitting immigrants with different ethnicities or those from poorer countries than towards admitting immigrants with the same ethnicity. Responses are also more positive on whether immigrants enrich the culture than on whether they are good for the economy or for the country in general. Scandinavians are generally more positive about immigration than other nationalities, while Czechs, Hungarians, Greeks and Portuguese respondents are more negative. But the most striking feature, shown in the lower panel of the table, is the evolution over time in these attitudes. Overall attitudes have changed very little in the wake of the global financial crisis. Not surprisingly the most marked decline is observed (for 2010) for the question on whether immigrants are good for the economy, but even this is reversed in 2012. Although these comparisons are affected by changing country coverage and within-country composition, as we shall see, the adjusted figures give essentially the same result.

\section{Immigration opinion across individuals and countries}

In order to assess macro-level effects on immigration opinion I use a two-step approach ${ }^{7}$ that is expressed as follows, where subscript $i$ is individual, $c$ is country and $t$ is year. For each country, individual opinion is characterized by:

$Y_{i c t}=X_{i c t} \alpha_{c}+u_{c t}+e_{i c t}$

Where $Y_{i c t}$ is the score for a particular opinion question and $X_{i c t}$ represents a set of individual characteristics. $\alpha_{c}$ is a vector of coefficients that differs by country, $u_{c t}$ is a set of countrylevel period fixed effects and $e_{i c t}$ is individual effects. Because we have repeated cross sections each individual only appears once and there is a separate regression for each country.

\footnotetext{
${ }^{7}$ For a discussion of alternative methods of estimating country-level effects see Bryan and Jenkins (2013); also Angrist and Pischke (2009) Ch. 8.
} 
The fixed effects $u_{c t}$ are period effects adjusted for individual-level composition and these are taken as the dependent variable at the second stage:

$u_{c t}=Z_{c t} \beta+d_{t}+v_{c}+\varepsilon_{c t}$

Where $Z_{c t}$ is a set of country-level variables, $B$ is a vector of coefficients assumed to be constant across countries, $d_{t}$ is a set of year dummies, $v_{c}$ is a set of country fixed effects and $\varepsilon_{\mathrm{ct}}$ is an idiosyncratic error term.

In equation (1) the dependent variable, $Y$, is simply the score for each variable as described earlier. $X$ includes just a few variables that are standard in the literature but it excludes other attitudinal variables, which are likely to be endogenous. To illustrate the typical individual effects, Table 2 presents regressions for all the countries and periods combined under the assumption that coefficients are common across all countries; $\alpha_{c}=\bar{a}$. These regressions are estimated for each of the six responses with 114 country/year effects and with standard errors clustered at that level.

As Table 2 shows, the effect of age (in years) is generally negative with varying magnitudes, while the gender effects vary considerably across the questions. Being born in the country has a large negative effect, indicating that immigrants are more pro-immigration, while being a member of an ethnic minority has an additional positive effect. Being in the labour force (employed or unemployed) has a negative effect, which would be consistent with job market competition, but also with concerns about the tax implications of immigration. High education (completed tertiary education) has a strong positive effect while mid-level education (upper secondary and post-secondary non-tertiary) has a smaller positive effect. Finally the interaction between labour market participation and high education is positive. This could also be interpreted as a labour market competition effect; the more educated the worker, the less he or she would fear competition from immigrants. Perhaps the most striking feature of these results is how similar the pattern of coefficients is across the range of different questions. The largest differences are in columns (4) relating to the economy and column (5) relating to the effects on the society's culture, but even those differences are mainly in the effects of gender and labour force participation. 
This specification could be used to adjust for composition, but the regressions in Table 2 impose the same slope coefficients across all countries. That would be inconsistent with the finding of studies that either allow the slopes to differ or that interact individual attributes with country-level variables such as GDP per capita (e.g. O’Rourke and Sinnott, 2006; Mayda 2006). In these studies differences in the slope coefficients across countries are interpreted as reflecting differences in the skill levels between natives and immigrants and possibly cultural differences between countries. Estimating these regressions separately for each country with year fixed effects reveals that the results do indeed differ between countries. This is illustrated in appendix Table A1 for the question on whether immigrants are good for the economy. The results show substantial differences across countries in the coefficients on age, sex, birthplace and minority status as well as differences in the effects of education and labour force participation.

I estimate separate regressions for each country for each of the six questions, as represented by equation (1). The period fixed effects are then recovered in order to assess the shifts in opinion over time. These are illustrated in Figure 1 for the question on whether immigrants are good for the economy. Here the gap between the gridlines is one unit of the dependent variable. The "North" group of countries exhibit mild trends with an uptick from 2010 to 2012 in Estonia, Finland and Norway and the opposite in Sweden. Not surprisingly, the "South" countries exhibit greater fluctuation with substantial declines in Spain, Greece, Portugal and especially Ireland. In the "East" group there is considerable diversity with a "U" shape in Hungary, downward trends in the Czech Republic and Slovakia and an upward trend in Poland. Finally in "Middle" Europe the trends are again fairly mild, with the important exception of Germany, which exhibits a striking upward trend. These composition-adjusted national effects are taken as the dependent variable for the countrylevel regressions in the next section.

\section{National effects on immigration opinion}

The trends in average Europe-wide opinion are shown in Table 3. These are the coefficients on period dummies in regressions on composition-adjusted opinion-the data illustrated in Figure 1 for the question on benefit to the economy. The omitted year is 2006 and the regressions also include country fixed effects. The changes over time are similar to those for 
the unadjusted data in the lower panel of Table 1 . For the policy-related questions in the first three columns there is evidence of a very mild upward trend with an almost imperceptible dip in 2010. In columns (4) to (6) there are also mild upward trends, with a temporary setback in 2010. However, as shown in Figure 1, these overall trends mask differences between countries that are likely to reflect the heterogeneity of experience over these years, especially in the depth of the recession following the global financial crisis.

I explore the influence of macroeconomic variables by estimating equation (2) for the fixed effects from the first stage, on five different economy-wide variables. The data sources are listed in the appendix. In Table 4, each row reports the coefficient when just one variable is entered in a regression with country fixed effects and year dummies (not reported). The first row shows that the foreign born percentage of population in the country has a negative effect on composition-adjusted opinion. ${ }^{8}$ This effect is present for all the different questions and, although modest in size, it is stronger than the effects that have been found in studies that rely on cross country variation. The second row shows the effect of the unemployment rate, which again is more strongly negative than is typically found in cross-sectional studies. Moving from column (1) to column (3) the coefficient increases in size and significance. Not surprisingly it is much stronger for the question on whether immigrants are good for the economy in column (4) than for the questions in the last two columns.

The third row of Table 4 shows the effect of the share of social benefits (cash and in-kind) in GDP, which reflects concerns about the fiscal effects of immigration. ${ }^{9}$ These effects are a little stronger than those for unemployment; the coefficients are negative in all six columns, and especially so for the column (4) relating to the economy. This is consistent with the importance of concerns about the tax implications of welfare spending but it may also reflect broader concerns about the state of the public finances. The effect of the financial deficit is examined in the fourth row. Here the pattern is similar to that for social benefits although the coefficients are smaller. It is possible that the apparent effects of the government budget simply reflect concerns about the recession more generally, i.e. the change in the denominator of the budget ratios rather than in the numerator. The fifth row

\footnotetext{
${ }^{8}$ Immigration may respond to public opinion in the destination country, either through immigration policy or because of changes in the social environment facing immigrants, but one would expect that correlation to be positive, not negative as found here.

${ }^{9}$ See OECD (2012) for a discussion of recent trends in social expenditure across the OECD.
} 
indicates that this is not the case. The effects of the log of real GDP per capita are insignificant for all the composition-adjusted attitudes except for whether immigration is good for the economy.

Table 5 reports four sets of regressions, each with three explanatory variables. As social benefits and the financial deficit are highly correlated they are not combined in one regression ${ }^{10}$. In the upper panel the coefficient on the foreign-born percentage remains negative and significant across all the six columns but the coefficient on the unemployment rate becomes small and insignificant except in column (4) relating to the economy. The middle panel shows that very similar results are obtained when the financial deficit is included in place of social benefits. Thus the two key influences on opinion towards immigration and immigrants are the scale of immigration and the state of the public finances, particularly expenditure on social welfare. ${ }^{11}$

One might expect that fiscal concerns would be greater where the net fiscal contribution of immigrants was more negative, even if these effects are imperfectly perceived. In order to test this hypothesis I use the difference between immigrants and non-immigrants in the ratio of fiscal benefits to contributions as estimated by the OECD for 2007-9 (OECD, 2013, Table 3 A4). This variable is available only for the cross section and so it is interacted with the ratio of social benefits to GDP. The interaction effect should be negative if fiscal concerns are greater the more negative is the net fiscal contribution of immigrants as compared with natives. The third panel of Table 5 shows that the main effect of social benefits remains negative and significant except in column (5) where it was previously insignificant. The interaction effect also takes a negative coefficient but the coefficient is only significant in columns (1) and (3). Although the interaction has somewhat stronger effects for the first three questions that relate to immigration policy it has no effect at all for the question on whether immigrants are good for the economy.

Finally, it is often argued that opinion is shaped by immigrants from non-western countries rather than by the total immigrant stock (Dustmann and Preston 2007; Schneider 2008).

\footnotetext{
${ }^{10}$ Taking the two variables as residuals from regressions with country fixed effects and year dummies, the correlation coefficient is 0.7 .

${ }^{11}$ This is consistent with research showing that perceptions of negative economic and moral consequences of the welfare state are correlated across countries with social expenditure per capita (Van Oorschot et al. 2012).
} 
Unfortunately there is no comprehensive annual series for the non-western share. Instead I take from 2000-1 round of censuses the share of all immigrants that was born in Africa, Asia and Latin America. This is interacted with the percentage of all immigrants in the population. If non-western immigrants are the focus then the interaction should be negative and the main effect should diminish in size and significance. But as bottom panel of Table 5 shows, the main effect remains significant in each of the six equations whereas the coefficient on the interaction is positive and insignificant except in the last column. It is notable that even in columns (2) and (3), which relate to immigrants with different ethnicities and those from poor countries, there is no evidence that the immigrant stock effect is stronger in countries were the non-western share is larger. Even though individual preferences clearly differ across different migrant sources, changes over time are driven by the total immigrant stock.

\section{Robustness checks}

The results so far indicate that the scale of immigration and fiscal concerns are at the heart of population-wide shifts in immigration opinion. It is worth asking how robust these results are. One question is whether the recession had its greatest influence by deflating proimmigration opinion or by further hardening anti-immigration opinion. This is tested by first converting immigration opinion into binary variables and estimating linear probability models for each country at the first stage. The fixed effects recovered from these estimates are then taken as the dependent variables for the second stage.

The upper panel of Table 6 presents the results when the threshold between pro- and antiimmigration is placed in the middle of the range. In this case dependent variable at the first stage takes the value 1 if the score on the question is greater than 5 . As the mean of the dependent variable at the first stage is now much smaller, the coefficients in the table are multiplied by ten. The results in Table 6 are fairly similar to those when the first stage was estimated over the full range of responses. In particular, in the first three columns relating to more or less immigration, all the coefficients on the percentage foreign born and the percentage of social benefits in GDP are negative and mostly significant while the unemployment rate is always insignificant. Allowing for scaling these resemble fairly closely the results in the upper panel of Table 5. By contrast the coefficients in columns (4) to (6) 
are a little weaker overall than the comparable results in Table 5 although they do follow the same general pattern. One reason is that the last three columns focus on one threshold out of ten in the scores on the original variable while the first three columns focus on one threshold out of three.

In the middle panel of Table 6 the dependent variable at the first stage takes the value 1 if the score on the question is greater than seven. The pattern of coefficients is again similar to that in Table 5, with the foreign born percentage and the social benefits share generally retaining significance. Again the significance levels are lower in columns (4) to (6) than the comparable results in Table 5. In the bottom panel the first stage dependent variable takes the value 1 if the score on the relevant question is greater than three. Here the size and significance of the coefficient on the foreign-born percentage decreases in the first three columns and increases in the second three, and while the effects of social benefits are a little stronger than for the higher cut-off in the middle panel the unemployment rate is insignificant, even in column (4). Thus while there are some differences across the different thresholds the effects are qualitatively similar. This suggests that the influence of the key variables in the recession have been fairly pervasive across different levels of opinion.

A second issue is whether the recession has had similar effects on opinion across different education levels. If the more highly educated have more liberal and perhaps longer term perspectives or feel less threatened by immigration then their opinion might be less responsive to the recession. The first stage regressions underlying Table 7 are estimated separately for each of the three education groups, dropping the observations for the others. Here the full range of scores is used at the first stage. In the upper panel the first stage is for those with high education (completed tertiary) and the results strongly resemble those in Table 5. However the coefficients in columns (4) to (6) are somewhat weaker, especially the coefficient on the percentage foreign born.

For the middle education group (completed upper secondary or post-secondary nontertiary) in the middle panel of Table 7 the coefficients on the two key variables are a shade stronger overall, especially for the questions on the value of immigrants in columns (4) to (6). Much the same can also be said for the results in the lower panel where the first stage regressions include only those with completed lower secondary education or less. While 
there are some differences across the three education groups the similarities are much more striking. This is especially so in the responses to the policy related questions in the first three columns where the coefficients are extremely similar for the three education groups. Insofar as macroeconomic conditions affect opinion they do so across all education levels and not just among the least educated. The first panel of Table 8 reports the F-test for the equality of coefficients across the three education groups that are reported in Table $7 .^{12}$ This restriction is rejected at the 5 percent level for the first question (despite the apparent similarity of the coefficients in column (1) of Table 7 and at the 1 percent level for the question on economic benefit in column (4). For the four other questions the hypothesis of equal coefficients is not rejected at conventional levels.

It might be thought that the opinions of younger people would be more influenced by the recession than older people whose opinions are more likely to have been set by past experience. ${ }^{13}$ Also the young might be more concerned with unemployment while older respondents are more concerned with social benefits. The results from estimating the first stage for those under the age of 40 and those aged 40 and above are presented in appendix Table A2. The second panel of Table 8 shows that the test for differences in the coefficients between the two age groups is never significant. ${ }^{14} \mathrm{~A}$ similar procedure is adopted for men versus women and the second stage results are reported in appendix Table A2. The test statistics for differences between the coefficients, in the third panel of Table 8, confirm that there are no significant differences by gender. One might expect that there would be differences in the response to the recession between those in the labour force and nonparticipants (also reported in Table A2). However the test statistics in the fourth panel of Table 8 show that there is no significant difference between the second stage coefficients. Among the possible group-wise differences one might expect the strongest to be between ethnic minorities and the ethnic majority population. But the last panel of Table 8 shows that these are insignificant, in part because the second stage coefficients are not very strong

\footnotetext{
12 This is a joint test for the interactions in a regression where the second stage regression includes interactions for high and low education. The test statistic is computed for the joint significance of the interactions; it therefore excludes any differences in the coefficients on the period dummies for the three different education groups.

${ }^{13}$ For the UK Duffy and Frere-Smith (2014) find that those born before 1965 became more negative towards immigration over the last decade (see also Ford 2011; Calahorrano, 2013).

${ }^{14}$ As an alternative I estimated the first stage using year of birth rather than age. The overall results (not shown here) were very close to those presented in Table 5 and the differences between those born before 1965 and those born later, when estimated separately, were not significant.
} 
for ethnic minorities (Table A2). Thus although there is a little evidence of differences by education group in responses to aggregate variables, there are no significant differences across age, sex, labour force participation and ethnic minority status.

Finally it is worth asking whether the results are largely driven by one country. The results of second stage regressions dropping one country at a time are presented in the appendix. Table $A 3$ reports the results for the question on the economic benefit of immigrants dropping one country at a time. These show very little change in the size and significance of the coefficients. An alternative is to interact the coefficients with a dummy for each country in turn. Tests of the joint significance of interaction terms for the question on whether immigrants are good for the economy are shown in Table 9. Not surprisingly the F-statistics are larger for some of the countries that experienced the greatest economic upheaval, such as Estonia, Greece and Ireland. But none of these are significant at the 5 percent level. The only country for which the interactions are significant is the Czech Republic and this is due to an unusually large negative coefficient on the foreign-born percentage. However, the magnitude and significance of the main effects are little altered and so the Czech Republic has been left in the dataset.

\section{Other attitudes and traits}

As noted above the cross sectional literature typically finds that immigration opinion is more strongly correlated with sociotropic cultural and political concerns than with economic selfinterest. These effects are often assessed by including a range of attitudes and traits as explanatory variables. These are likely to be endogenous and they may also have shifted in response to the economic crisis. If so, then variables that are sometimes seen as noneconomic may be capturing changing economic conditions. Here I look at six questions that have been linked with immigration opinion. The questions are as follows:

- Generally speaking, would you say that most people can be trusted, or that you can't be too careful in dealing with people? Please tell me on a score of 0 to 10 , where 0 means you can't be too careful and 10 means that most people can be trusted.

- It is important to [a person] to live in secure surroundings. She/he avoids anything that might endanger her/his safety. Please tell me how much each person is or is not like you. (Range: 1 = very much like me $\rightarrow 6=$ not like me at all). 
- Tradition is important to [a person]. She/he tries to follow the customs handed down by her/his religion or her/his family. Please tell me how much each person is or is not like you. (Range: $1=$ very much like me $\rightarrow 6=$ not like me at all).

- Please tell me on a score of 0-10 how much you personally trust each of the institutions I read out. 0 means you do not trust an institution at all, and 10 means you have complete trust. Firstly... politicians?

- Now thinking about the [country] government, how satisfied are you with the way it is doing its job? (Range: $0=$ extremely dissatisfied $\rightarrow 10=$ extremely satisfied).

- In politics people sometimes talk of "left" and "right". Where would you place yourself on this scale, where 0 means the left and 10 means the right?

The first three questions relate to human values. The willingness to trust people and the importance placed on security reflect the degree to which individuals feel vulnerable to external threats (for links to immigration opinion see: Herreros and Criado, 2008; Rustenbach 2010). The importance placed on traditions reflects the individual's cultural conservatism, a trait that is often linked with resistance to immigrants from non-western countries (O'Rourke and Sinnott 2006; Ford 2011; Manevska and Achterberg 2013). The next three questions relate to political opinion. Lack of trust in politicians reflects the degree of cynicism towards politicians and in particular their motivations or their competence. Satisfaction with the government captures the perceived policy effectiveness of the current government. And finally, self-placement on the left or right of the political scale is often seen as closely linked with opinion on immigration: the further to the right the more negative the individual's attitude to immigration (Mayda 2006; Sides and Citrin 2007).

Each of these variables is composition-adjusted using a regression for each country (equation (1) above) with the same set of explanatory variables that appear in the regressions of Table 2. As with the responses to the questions on immigration, the nationallevel variations are obtained by recovering the period fixed effects from the regression for each question/country. These fixed effects were regressed on a set of period dummies as was done for the questions on immigration in Table 3. The results are reported in Table 10. For the human values in the first three columns there is some evidence of an increase in trust, no trend in the importance of safety, and perhaps some slight decline in the 
importance of customs and traditions. Column (4) shows that trust in politicians declined after 2002 with a further dip in 2010 and this is replicated more mildly for the degree of satisfaction with the government (column 5). Finally on the left-right scale there is a small but insignificant drift to the right.

The shifts in these attitudes are fairly small but, just as with immigration opinion, there are differences between countries. In order to explore the relationships between immigration opinion and these other attitudes and traits, the residuals from the regressions in Table 10 were correlated with the residuals from the Table 3 regressions on immigration opinion. Thus the correlation coefficients in Table 11 are from country/year observations that are purged of composition effects, of country effects and of common period effects. If these residual traits or attitudes do not shift over time in concert with immigration opinion then the correlations should be close to zero. In fact some of them are highly significant $\left(^{*}=\right.$ significant at the 1 percent level). They show that shifts in attitudes to immigration are strongly associated with shifts in personal trust (those with greater trust are more proimmigration) but not with shifts attitudes towards safety and traditions. Not surprisingly, trust in politicians and satisfaction with the government is also positively correlated with immigration opinion. But more counter-intuitive is the positive correlation between shifts in self-placement on the left-right scale and immigration opinion. This indicates, at least for shifts over time, that more positive opinion towards immigration is associated with shifts to the right.

The correlations between immigration opinion and other attitudes or traits invites the question of whether these attitudes shifted in response to the same underlying variables. Table 12 shows the result of taking each of these attitudes as the dependent variable. As before, each of the dependent variables is the composition-adjusted period fixed effect derived from first-stage regressions for each country using the same explanatory variables as in Table 2. The regressions in Table 12 include country fixed effects and period dummies. The first three regressions in the upper panel show that the share of foreign born matters for the importance of safety (column 2) and that increasing social benefits reinforces the importance of traditions. Interestingly, columns (4) and (5) show that mistrust of the politicians and dissatisfaction with the government are both positively related to the share of social benefits and somewhat more weakly to the unemployment rate. 
The last column of Table 12 shows, somewhat surprisingly, that the share of social benefits in GDP is negatively associated with shifts to the right on the political spectrum. The lower panel of the table shows that similar results are obtained when the social benefits share is replaced in the regression by the financial deficit. But overall, the most striking result to emerge from Table 12 is that changes in the share of social benefits over the period spanning the global financial crisis seem to have influenced attitudes and traits that have often been linked to opinion on immigration.

Clearly the correlation between opinion on immigration and these other attitudes and traits cannot be regarded as causal. ${ }^{15}$ However, it is worth asking if any correlation remains once the effect of macro-level variables is taken into account. Table 13 reports regressions where four of the attitudinal variables (those with significant correlations in Table 11) are added to the regressions explaining immigration opinion. These variables are the residuals from the regressions in the upper panel of Table 12. Thus they are purged of composition, common period effects and the effects of the three macro-level explanatory variables in Table 12.

The results in Table 13 show that there are some remaining correlations. The variable trust in people takes a positive and significant coefficient in all six regressions. Similarly trust in politicians has some residual correlation which is positive and significant for four out of the six questions. This suggests that there are elements in changing average trust that are correlated with immigration opinion but are not fully captured by the three macro-level variables. By contrast residual satisfaction with the government is uniformly insignificant. Thus all the relevant variation is absorbed by the three economic variables, especially the share of social benefits in GDP. Lastly the positive correlation between immigration opinion and self-placement on the left-right scale re-emerges even after the common macro-level elements are removed. This finding contrasts sharply with the view that anti-immigration opinion is driven by, or is associated with, societal lurches to the right. On one hand there has been very little Europe-wide shift to the right; but on the other hand rightward shifts are positively associated with pro-immigration opinion, at least at the macro-level.

\section{Discussion}

\footnotetext{
${ }^{15}$ For example McLaren (2012) argues that trust in (the UK) parliament and politicians depends in part on concerns about immigration. For the Netherlands, De Vries et al. (2013) suggest that left right self-placement depends increasingly on attitudes to immigration.
} 
This paper explores the links between composition-adjusted average opinion on immigration and the macro-level variables that are often thought to influence it. This is important for two reasons. One is that there have been few convincing attempts to measure such effects. The magnitude of the recent recession and its widely varying incidence provides a unique opportunity to evaluate them. The other is that, in the context of the recent policy debate, some commentators have drawn strong conclusions about how and why opinion has shifted in recent years. These often seem to be based on media-driven rhetoric rather than on the results of research on public attitudes.

The most striking finding that emerges from the analysis of six rounds of the ESS is how little opinion on immigration has changed since before the recession. This is consistent with the findings of cross sectional analyses that stress the importance of variables like education and demography-variables that shift only slowly over time. Even allowing for compositional change there seems to be a very mild positive trend in opinion towards immigrants, on average across Europe, with a very slight setback in the few years following the recession. This is partly because the recession itself has been comparatively mild in some countries and partly because fluctuations in immigration and in macroeconomic conditions have had modest effects on average opinion

Although the effects are modest in size, there is strong evidence that nation-wide indicators do affect opinion on immigrants and immigration. The evidence suggests that these shifts in opinion occur across-the-board; they differ very little across demographic groups. But the most important result is that the key influences on average opinion are the percentage of foreign born in the population and the share of social spending in GDP. Once these are taken into account the unemployment rate has very little effect. These findings resonate with the recent academic debate, where the focus has shifted from labour market effects to fiscal effects, and also with the focus (although perhaps not the tenor) of recent political debate. But the result may be specific to the aftermath of the global financial crisis in which welfare spending and rising budget deficits have gone hand in hand. Thus it is impossible to distinguish the impact on immigration opinion of the welfare burden from that of the financial deficit. Either way it seems likely that they signal austerity measures that imply tax rises for some and benefit cuts for others. Although the coefficients are modest the impact is substantial for some of the countries that were worst hit by the recession. Between 2006 
and 2010 the effect of the rise in social benefits on responses to the question on whether immigrants are good for the economy was -0.78 points in Ireland, -0.54 in Spain and -0.42 in Greece (on the scale 0 to 10). In consequence it seems very likely that immigration opinion will become more favourable as the share of welfare spending falls in the recovery.

These key variables also influenced other traits and attitudes that are often used to explain immigration opinion. The discord sown by the recession seems to have weakened personal trust, and the perceived failures of economic management tended to undermine the public's faith in politicians and governments. While dissatisfaction with the government is clearly associated with rising unemployment and social spending, the temporary decline in trust is probably associated more with the general increase in uncertainty. More intriguing are the trends in self-placement on the left-right political scale. Although anti-immigration politics and policy is often associated with increases in the influence of far right populist parties, we observe only a very mild rightward shift in the underlying political attitudes. More important still, the rightward trend in political stance has not been associated with negative shifts in immigration opinion-if anything it has been the reverse.

The results reported here provide some background to the recent surge in support for rightwing populist parties. Although an anti-immigrant stance is one thing that such parties share in common this trend does not seem to have been underpinned by an upsurge in public opinion against immigration. Rather, by conflating their euro-sceptic and anti-bailout platforms with a broad anti-immigration stance such parties seem have found a combination that taps into a segment of pre-existing attitudes. And while it is tempting to think that the recession has helped to convert such opinion into protest votes there is some reason to doubt even that. After all, the resurgence of right wing populism has been far more prominent in northern Europe than in the recession-hit south. 


\section{References}

Angrist J. D. and Pischke, J-S. (2009), Mostly Harmless Econometrics: An Empiricist's Companion, New Jersey: Princeton University Press.

Boeri, T. (2010), “Immigration to the Land of Redistribution," Economica, 77, pp. 651-87.

Bryan, M. L. and Jenkins, S. P. (2013) "Regression Analysis of Country Effects using Multilevel Data: A Cautionary Tale," IZA Discussion Paper 7583.

Calahorrano, L. (2013), "Population Aging and Individual Attitudes toward Immigration: Disentangling Age, Cohort and Time Effects," Review of International Economics, 21, pp. 342-353.

Card, D., Dustmann, C. and Preston, I. P. (2012), "Immigration, Wages, and Compositional Amenities," Journal of the European Economic Association, 10, pp. 78-119.

Ceobanu, A. M. and Escandell, X. (2010), "Comparative Analyses of Public Attitudes Toward Immigrants and Immigration Using Multinational Survey Data: A Review of Theories and Research," Annual Review of Sociology, 36, pp. 309-28.

Citrin, J., Green, D., Muste, C. and Wong, C. (1997), "Public Opinion toward Immigration Reform: The Role of Economic Motivations," Journal of Politics, 59, pp. 858-81.

Coenders, M. and Scheepers, P. (2008), "Changes in Resistance to the Social Integration of Foreigners in Germany 1980-2000: Individual and Contextual Determinants," Journal of Ethnic and Migration Studies, 34, pp. 1-26.

Creighton, M. J., Jamal, A. and Malanci, N. C. (2014), "Has Opposition to Immigration Increased in the U.S. after the Economic Crisis? An Experimental Approach," International Migration Review (early view).

Dancygier, R. M. and Donnelly, M. J. (2013), "Sectoral Economies, Economic Contexts, and Attitudes toward Immigration," Journal of Politics, 75, pp. 17-35.

De Vries, C. E., Hakhverdian, A. and Lancee, B. (2013), "The Dynamics of Voters' Left/Right Identification: The Role of Economic and Cultural Attitudes," Political Science Research and Methods, 1 , pp. 223 - 238.

Denny, K. and Ó Gráda, C. (2013), "Irish Attitudes to Immigration During and After the Boom," University College Dublin Centre for Economic Research Working Paper No. 13/18.

Duffy, B. and Frere-Smith, T. (2014), "Perceptions and Reality: Public Attitudes to Immigration" Ipsos-MORI Social Research Institute, at: http://www.ipsosmori.com/DownloadPublication/1634 sri-perceptions-and-reality-immigration-report2013.pdf

Dustmann, C. and I. P. Preston (2001), "Attitudes to Ethnic Minorities, Ethnic Context and Location Decisions," Economic Journal, 111, pp. 353-373. 
Dustmann, C. and Preston, I. P. (2007), "Racial and Economic Factors in Attitudes to Immigration," Berkeley Electronic Journal of Economic Analysis \& Policy, Advances 7, Art 62.

Facchini, G. and Mayda, A. M. (2009), "Does the Welfare State Affect Individual Attitudes toward Immigrants?" Review of Economics and Statistics, 91, pp. 295-314.

Facchini, G. and Mayda, A. M. (2012), "Individual Attitudes towards Skilled Migration: An Empirical Analysis across Countries," World Economy, 35, pp. 183-196.

Ford, R. (2011), "Acceptable and Unacceptable Immigrants: How Opposition to Immigration in Britain is Affected by Migrants' Region of Origin," Journal of Ethnic and Migration Studies, 37, pp. 1017-1037.

Gang, I. N., Rivera-Batiz, F. L. and Yun, M-S. (2013), "Economic Strain, Education and Attitudes towards Foreigners in the European Union," Review of International Economics 21, pp.177-190.

Goldstein, J. L. and Peters, M. E. (2014), "Nativism or Economic Threat: Attitudes toward Immigrants during the Great Recession," International Interactions, forthcoming.

Hainmueller, J. and Hiscox, M. J. (2007), “Educated Preferences: Explaining Individual Attitudes toward Immigration in Europe," International Organization, 61, pp. 399-442.

Hainmueller, J. and Hiscox, M. J. (2010), "Attitudes toward Highly Skilled and Low-Skilled Immigration: Evidence from a Survey Experiment," American Political Science Review, 104, pp. 61-84.

Hainmueller, J. and Hopkins, D. (2014), "Public Attitudes toward Immigration," Annual Review of Political Science, 17, pp. 11.1-11.25.

Hanson G. H., Scheve, K. F. and Slaughter, M. J. (2007), "Public Finance and Individual Preferences over Globalization Strategies," Economics and Politics, 19, pp. 1-33.

Hericourt, J. and Spielvogel, G. (2012), "How Beliefs about the Impact of Immigration Shape Policy Preferences: Evidence from Europe," UMR DIAL Discussion paper 2012-06.

Herreros, F. and Criado, H. (2008), "Social Trust, Social Capital and Perceptions of Immigration," Political Studies, 57, pp. 337-355.

Ivarsflaten, E. (2005) "The Vulnerable Populist Right Parties: No Economic Realignment Fuelling their Electoral Success," European Journal of Political Research, 44, pp. 465-492.

Jäckle, A., Roberts, C. and Lynn, P. (2010), "Assessing the Effect of Data Collection Mode on Measurement," International Statistical Review, 78, pp. 3-30.

Lahav, G. (2004), "Public Opinion toward Immigration in the European Union: Does it Matter?" Comparative Political Studies, 37, pp. 1151-1183. 
Lucassen, G. and Lubbers, M. (2012), "Who Fears What? Explaining Far-Right-Wing Preference in Europe by Distinguishing Perceived Cultural and Economic Ethnic Threats," Comparative Political Studies, 45, pp. 547-574

Malhotra, N., Margalit, Y. and Mo, C. H. (2013), "Economic Explanations for Opposition to Immigration: Distinguishing between Prevalence and Conditional Impact," American Journal of Political Science, 57, pp. 391-410.

Manevska, K. and Achterberg, P. (2013), "Immigration and Perceived Ethnic Threat: Cultural Capital and Economic Explanations," European Sociological Review, 29, pp. 437-449.

Markaki, Y. and Longhi, S. (2013), "What determines attitudes to immigration in European countries? An analysis at the regional level," Migration Studies, 1, pp. 311-337.

Mayda, A. M. (2006), "Who is Against Immigration? A Cross-Country Investigation of Attitudes towards Immigrants," Review of Economics and Statistics, 88, pp. 510-30.

McLaren L. M. (2012), "Immigration and Trust in Politics in Britain," British Journal of Political Science, 42, pp. 163-185.

Meuleman, B., Davidov, E. and Billiet, J. (2009), "Changing Attitudes toward Immigration in Europe, 2002-2007: A Dynamic Group Conflict Theory Approach," Social Science Research, 38, pp. 352-365.

Mudde, C. (2007), Populist Radical Right Parties in Europe, Cambridge: Cambridge University Press.

OECD (2012), "Social Spending During the Crisis," at:

http://www.oecd.org/els/soc/OECD2012SocialSpendingDuringTheCrisis8pages.pdf.

OECD (2013), International Migration Outlook 2013, Paris: OECD.

O'Rourke, K. H. and Sinnott, R. (2006), "The Determinants of Individual Attitudes towards Immigration," European Journal of Political Economy, 22, pp. 838-61.

Rustenbach, E. (2010), "Sources of Negative Attitudes toward Immigrants in Europe: A Multi-Level Analysis," International Migration Review, 44, pp. 53-77.

Rydgren, J. (2008), "Immigration Sceptics, Xenophobes or Racists? Radical Right-Wing Voting in Six West European Countries," European Journal of Political Research 47, pp. 737-65.

Scheve, K. F. and Slaughter, M. J. (2001), "Labor Market Competition and Individual Preferences over Immigration Policy," Review of Economics and Statistics, 83, pp. 133-45.

Schneider, S. L. (2008), “Anti-Immigrant Attitudes in Europe: Outgroup Size and Perceived Ethnic Threat," European Sociological Review, 24 pp. 53-67. 
Semyonov, M., Raijman, R. and Gorodzeisky, A. (2008), “Foreigners' Impact on European Societies: Public Views and Perceptions in a Cross-National Comparative Perspective," International Journal of Comparative Sociology, 49, pp. 5-29.

Sides, J. and Citrin, J. (2007), "European Opinion about Immigration: The Role of Identities, Interests and Information," British Journal of Political Science, 37, pp. 477-504.

Sniderman, P. M., Hagendoorn, L. and Prior, M. (2004), "Predisposing Factors and Situational Triggers: Exclusionary Reactions to Immigrant Minorities," American Political Science Review, 98, pp. 34-49.

Van Oorschot, W., Reeskens, T. and Meuleman B. (2012), "Popular perceptions of welfare state consequences: A multilevel, cross-national analysis of 25 European countries," Journal of European Social Policy, 22 pp. 181-197.

Wilkes, R. and Corrigall-Brown, C. (2011), "Explaining time trends in public opinion: Attitudes towards immigration and immigrants," International Journal of Comparative Sociology, 52, pp. 79-99. 
Table 1: Average opinion by country and year

\begin{tabular}{|l|r|r|r|r|r|r|}
\hline & $\begin{array}{l}\text { More/less } \\
\text { same } \\
\text { ethnic grp }\end{array}$ & $\begin{array}{l}\text { More/less } \\
\text { different } \\
\text { ethnic grp }\end{array}$ & $\begin{array}{l}\text { More/less } \\
\text { from poor } \\
\text { countries }\end{array}$ & $\begin{array}{l}\text { Immigrt } \\
\text { good for } \\
\text { economy }\end{array}$ & $\begin{array}{l}\text { Immigrt } \\
\text { enrich } \\
\text { culture }\end{array}$ & $\begin{array}{l}\text { Immigrt } \\
\text { better } \\
\text { place }\end{array}$ \\
\hline Country (rounds) & & & & & & \\
\hline Belgium (6) & 5.63 & 5.01 & 5.02 & 4.59 & 5.74 & 4.63 \\
\hline Switzerland (6) & 6.07 & 5.37 & 5.32 & 5.96 & 6.11 & 5.34 \\
\hline Czech Republic (5) & 4.93 & 4.46 & 4.47 & 4.20 & 4.42 & 4.25 \\
\hline Germany (6) & 6.03 & 5.30 & 5.19 & 5.15 & 5.99 & 4.99 \\
\hline Denmark (6) & 6.10 & 5.19 & 4.94 & 5.11 & 6.01 & 5.72 \\
\hline Estonia (5) & 5.65 & 4.62 & 4.07 & 4.60 & 5.16 & 4.33 \\
\hline Spain (6) & 5.25 & 5.10 & 5.10 & 5.35 & 5.93 & 5.06 \\
\hline Finland (6) & 5.44 & 4.81 & 4.62 & 5.33 & 7.13 & 5.46 \\
\hline France (5) & 5.42 & 5.05 & 4.87 & 4.85 & 5.27 & 4.60 \\
\hline Great Britain (6) & 5.30 & 4.91 & 4.76 & 4.56 & 5.00 & 4.62 \\
\hline Greece (4) & 4.76 & 3.79 & 3.73 & 3.53 & 3.47 & 3.21 \\
\hline Hungary (6) & 5.34 & 3.90 & 3.66 & 3.84 & 5.21 & 4.09 \\
\hline Ireland (6) & 5.68 & 5.30 & 5.22 & 5.20 & 5.65 & 5.46 \\
\hline Netherlands (6) & 5.43 & 5.20 & 5.01 & 5.08 & 6.10 & 5.06 \\
\hline Norway (6) & 6.01 & 5.45 & 5.42 & 5.58 & 5.89 & 5.18 \\
\hline Poland (6) & 5.94 & 5.56 & 5.60 & 5.17 & 6.43 & 5.73 \\
\hline Portugal (6) & 4.51 & 4.32 & 4.26 & 4.67 & 5.18 & 4.03 \\
\hline Sweden (6) & 6.49 & 6.32 & 6.28 & 5.49 & 7.03 & 6.23 \\
\hline Slovenia (6) & 5.57 & 5.22 & 4.99 & 4.34 & 5.18 & 4.60 \\
\hline Slovakia(5) & 5.55 & 5.05 & 5.02 & 4.22 & 5.04 & 4.40 \\
\hline Year (no. countries) & & & & & & 4.74 \\
\hline 2002 (18) & 5.48 & 4.98 & 4.99 & 4.84 & 5.68 & 4.74 \\
\hline 2004 (20) & 5.61 & 5.93 & 4.85 & 4.67 & 5.52 & 4.74 \\
\hline 2006 (18) & 5.59 & 4.99 & 4.81 & 4.78 & 5.50 & 4.86 \\
\hline 2008 (20) & 5.67 & 5.19 & 4.99 & 5.05 & 5.88 & 5.17 \\
\hline 2010 (20) & & & & 5.04 & 5.75 & 4.95 \\
\hline 2012 (18) & 5.04 & 4.90 & 4.91 & 5.64 & 4.92 \\
\hline
\end{tabular}

Source: European Social Survey cumulative data file rounds 1-5 (2002-10) and round 6 data file (2012), edition 2.0. Norwegian Social Science Data Services, Norway - Data Archive and distributor of ESS data. 
Table 2: Correlates of opinion across individuals

\begin{tabular}{|c|c|c|c|c|c|c|}
\hline & (1) & (2) & (3) & (4) & (5) & (6) \\
\hline & $\begin{array}{l}\text { More/less } \\
\text { same } \\
\text { ethnic grp }\end{array}$ & $\begin{array}{l}\text { More/less } \\
\text { different } \\
\text { ethnic grp }\end{array}$ & $\begin{array}{l}\text { More/less } \\
\text { from poor } \\
\text { countries }\end{array}$ & $\begin{array}{l}\text { Immigrt } \\
\text { good for } \\
\text { economy }\end{array}$ & $\begin{array}{l}\text { Immigrt } \\
\text { enrich } \\
\text { culture }\end{array}$ & $\begin{array}{l}\text { Immigrt } \\
\text { better } \\
\text { place }\end{array}$ \\
\hline Age & $\begin{array}{r}-0.097 \\
(18.96)\end{array}$ & $\begin{array}{r}-0.004 \\
(23.09)\end{array}$ & $\begin{array}{r}-0.015 \\
(27.14)\end{array}$ & $\begin{array}{r}-0.006 \\
(7.39)\end{array}$ & $\begin{array}{r}-0.011 \\
(14.18)\end{array}$ & $\begin{array}{r}-0.103 \\
(12.51)\end{array}$ \\
\hline Female & $\begin{array}{l}0.052 \\
(4.03)\end{array}$ & $\begin{array}{l}0.061 \\
(1.08)\end{array}$ & $\begin{array}{l}0.025 \\
(1.70)\end{array}$ & $\begin{array}{r}0.285 \\
(16.68)\end{array}$ & $\begin{array}{r}-0.054 \\
(2.36)\end{array}$ & $\begin{array}{l}0.037 \\
(1.90)\end{array}$ \\
\hline Born in country & $\begin{array}{r}-0.339 \\
(10.85) \\
\end{array}$ & $\begin{array}{r}-0.365 \\
(11.37) \\
\end{array}$ & $\begin{array}{r}-0.336 \\
(10.21) \\
\end{array}$ & $\begin{array}{r}-0.765 \\
(14.37) \\
\end{array}$ & $\begin{array}{r}-0.700 \\
(13.89) \\
\end{array}$ & $\begin{array}{r}-0.823 \\
(17.83) \\
\end{array}$ \\
\hline Ethnic minority & $\begin{array}{l}0.078 \\
(3.13) \\
\end{array}$ & $\begin{array}{l}0.190 \\
(8.03)\end{array}$ & $\begin{array}{l}0.205 \\
(8.18)\end{array}$ & $\begin{array}{l}0.295 \\
(7.55)\end{array}$ & $\begin{array}{l}0.346 \\
(8.02) \\
\end{array}$ & $\begin{array}{l}0.341 \\
(8.80)\end{array}$ \\
\hline $\begin{array}{l}\text { Labour force } \\
\text { participant }\end{array}$ & $\begin{array}{r}-0.091 \\
(6.63) \\
\end{array}$ & $\begin{array}{r}-0.076 \\
(5.67)\end{array}$ & $\begin{array}{r}-0.085 \\
(6.25)\end{array}$ & $\begin{array}{r}-0.106 \\
(5.84)\end{array}$ & $\begin{array}{r}-0.013 \\
(0.75)\end{array}$ & $\begin{array}{r}-0.051 \\
(3.04)\end{array}$ \\
\hline High education & $\begin{array}{r}0.729 \\
(37.22)\end{array}$ & $\begin{array}{r}0.717 \\
(33.95)\end{array}$ & $\begin{array}{r}0.588 \\
(27.76)\end{array}$ & $\begin{array}{r}1.145 \\
(42.05)\end{array}$ & $\begin{array}{r}1.146 \\
(33.39)\end{array}$ & $\begin{array}{r}0.903 \\
(26.37)\end{array}$ \\
\hline Mid-level education & $\begin{array}{r}0.262 \\
(16.26) \\
\end{array}$ & $\begin{array}{r}0.268 \\
(16.61) \\
\end{array}$ & $\begin{array}{r}0.186 \\
(11.07) \\
\end{array}$ & $\begin{array}{r}0.395 \\
(19.48) \\
\end{array}$ & $\begin{array}{r}0.445 \\
(22.21) \\
\end{array}$ & $\begin{array}{r}0.320 \\
(16.10) \\
\end{array}$ \\
\hline $\begin{array}{l}\text { High education * } \\
\text { participant }\end{array}$ & $\begin{array}{l}0.082 \\
(4.16)\end{array}$ & $\begin{array}{l}0.182 \\
(9.35)\end{array}$ & $\begin{array}{l}0.155 \\
(7.65)\end{array}$ & $\begin{array}{l}0.196 \\
(6.24)\end{array}$ & $\begin{array}{l}0.221 \\
(7.38)\end{array}$ & $\begin{array}{l}0.170 \\
(5.55)\end{array}$ \\
\hline $\mathrm{R}^{2}$ within & 0.051 & 0.071 & 0.061 & 0.063 & 0.068 & 0.060 \\
\hline between & 0.507 & 0.206 & 0.126 & 0.165 & 0.072 & 0.170 \\
\hline overall & 0.065 & 0.076 & 0.062 & 0.068 & 0.067 & 0.064 \\
\hline Country/years & 114 & 114 & 114 & 114 & 114 & 114 \\
\hline Observations & 203200 & 203034 & 202743 & 200581 & 200996 & 200726 \\
\hline
\end{tabular}

Note: Fixed effects by country/year. ' $z$ ' statistics in parentheses computed from standard errors clustered by country/year. 
Table 3: Year effects on immigration opinion

\begin{tabular}{|c|c|c|c|c|c|c|}
\hline & (1) & (2) & (3) & (4) & (5) & (6) \\
\hline & $\begin{array}{l}\text { More/less } \\
\text { same } \\
\text { ethnic grp }\end{array}$ & $\begin{array}{l}\text { More/less } \\
\text { different } \\
\text { ethnic grp }\end{array}$ & $\begin{array}{l}\text { More/less } \\
\text { from poor } \\
\text { countries }\end{array}$ & $\begin{array}{l}\text { Immigrt } \\
\text { good for } \\
\text { economy }\end{array}$ & $\begin{array}{l}\text { Immigrt } \\
\text { enrich } \\
\text { culture }\end{array}$ & $\begin{array}{l}\text { Immigrt } \\
\text { better } \\
\text { place }\end{array}$ \\
\hline 2002 & $\begin{array}{r}-0.033 \\
(0.47)\end{array}$ & $\begin{array}{l}0.043 \\
(0.68)\end{array}$ & $\begin{array}{r}0.138 \\
(2.12)\end{array}$ & $\begin{array}{r}-0.085 \\
(0.85)\end{array}$ & $\begin{array}{r}-0.119 \\
(1.72)\end{array}$ & $\begin{array}{r}-0.097 \\
(1.43)\end{array}$ \\
\hline 2004 & $\begin{array}{r}-0.017 \\
(0.25)\end{array}$ & $\begin{array}{l}0.005 \\
(0.09)\end{array}$ & $\begin{array}{l}0.012 \\
(0.19)\end{array}$ & $\begin{array}{r}-0.227 \\
(2.36)\end{array}$ & $\begin{array}{r}-0.023 \\
(0.35)\end{array}$ & $\begin{array}{r}-0.071 \\
(1.09)\end{array}$ \\
\hline 2008 & $\begin{array}{l}0.058 \\
(0.87)\end{array}$ & $\begin{array}{c}0.100 \\
(1.63)\end{array}$ & $\begin{array}{l}0.055 \\
(0.88)\end{array}$ & $\begin{array}{r}-0.035 \\
(0.37)\end{array}$ & $\begin{array}{l}0.057 \\
(0.85)\end{array}$ & $\begin{array}{c}0.071 \\
(1.07)\end{array}$ \\
\hline 2010 & $\begin{array}{r}0.046 \\
(0.68) \\
\end{array}$ & $\begin{array}{r}0.055 \\
(0.90) \\
\end{array}$ & $\begin{array}{r}-0.028 \\
(0.44)\end{array}$ & $\begin{array}{r}-0.180 \\
(1.87)\end{array}$ & $\begin{array}{r}-0.073 \\
(1.08) \\
\end{array}$ & $\begin{array}{r}0.018 \\
(0.28) \\
\end{array}$ \\
\hline 2012 & $\begin{array}{l}0.065 \\
(0.95)\end{array}$ & $\begin{array}{l}0.177 \\
(2.83)\end{array}$ & $\begin{array}{l}0.083 \\
(1.29)\end{array}$ & $\begin{array}{l}0.025 \\
(0.25)\end{array}$ & $\begin{array}{l}0.161 \\
(2.32)\end{array}$ & $\begin{array}{l}0.237 \\
(3.50)\end{array}$ \\
\hline $\mathrm{R}^{2}$ within & 0.042 & 0.115 & 0.094 & 0.111 & 0.163 & 0.263 \\
\hline$F$ (p-value) & 0.574 & 0.050 & 0.112 & 0.098 & 0.007 & 0.000 \\
\hline Observations & 114 & 114 & 114 & 114 & 114 & 114 \\
\hline
\end{tabular}

Note: Fixed effects by country; ' $z$ ' statistics in parentheses.

Table 4: Bivariate regressions for national-level indicators on opinion

\begin{tabular}{|c|c|c|c|c|c|c|}
\hline & (1) & (2) & (3) & (4) & (5) & (6) \\
\hline & $\begin{array}{l}\text { More/less } \\
\text { same } \\
\text { ethnic grp }\end{array}$ & $\begin{array}{l}\text { More/less } \\
\text { different } \\
\text { ethnic grp }\end{array}$ & $\begin{array}{l}\text { More/less } \\
\text { from poor } \\
\text { countries }\end{array}$ & $\begin{array}{l}\text { Immigrt } \\
\text { good for } \\
\text { economy }\end{array}$ & $\begin{array}{l}\text { Immigrt } \\
\text { enrich } \\
\text { culture }\end{array}$ & $\begin{array}{l}\text { Immigrt } \\
\text { better } \\
\text { place }\end{array}$ \\
\hline Foreign-born (\%) & $\begin{array}{r}-0.076 \\
(5.24)\end{array}$ & $\begin{array}{r}-0.049 \\
(3.41)\end{array}$ & $\begin{array}{r}-0.048 \\
(3.24)\end{array}$ & $\begin{array}{r}-0.067 \\
(2.93)\end{array}$ & $\begin{array}{r}-0.046 \\
(2.89)\end{array}$ & $\begin{array}{r}-0.034 \\
(2.12)\end{array}$ \\
\hline$R^{2}$ between & 0.270 & 0.218 & 0.191 & 0.190 & 0.235 & 0.299 \\
\hline $\begin{array}{l}\text { Unemployment rate } \\
\text { (\%) }\end{array}$ & $\begin{array}{r}-0.011 \\
(1.35)\end{array}$ & $\begin{array}{r}-0.015 \\
(2.02)\end{array}$ & $\begin{array}{r}-0.019 \\
(2.49)\end{array}$ & $\begin{array}{r}-0.055 \\
(5.23)\end{array}$ & $\begin{array}{l}0.000 \\
(0.02)\end{array}$ & $\begin{array}{r}-0.018 \\
(2.20)\end{array}$ \\
\hline $\mathrm{R}^{2}$ between & 0.061 & 0.154 & 0.154 & 0.307 & 0.163 & 0.302 \\
\hline $\begin{array}{l}\text { Social benefits \% of } \\
\text { GDP }\end{array}$ & $\begin{array}{r}-0.039 \\
(2.90) \\
\end{array}$ & $\begin{array}{r}-0.042 \\
(3.48) \\
\end{array}$ & $\begin{array}{r}-0.051 \\
(4.23) \\
\end{array}$ & $\begin{array}{r}-0.115 \\
(7.13) \\
\end{array}$ & $\begin{array}{r}-0.019 \\
(1.33) \\
\end{array}$ & $\begin{array}{r}-0.048 \\
(3.73) \\
\end{array}$ \\
\hline $\mathrm{R}^{2}$ between & 0.125 & 0.222 & 0.247 & 0.437 & 0.180 & 0.363 \\
\hline $\begin{array}{l}\text { Financial deficit \% of } \\
\text { GDP }\end{array}$ & $\begin{array}{r}-0.024 \\
(3.98) \\
\end{array}$ & $\begin{array}{r}-0.016 \\
(2.80) \\
\end{array}$ & $\begin{array}{r}-0.017 \\
(3.03) \\
\end{array}$ & $\begin{array}{r}-0.047 \\
(5.99) \\
\end{array}$ & $\begin{array}{r}-0.013 \\
(1.97) \\
\end{array}$ & $\begin{array}{r}-0.019 \\
(3.17) \\
\end{array}$ \\
\hline $\mathrm{R}^{2}$ between & 0.188 & 0.187 & 0.180 & 0.369 & 0.198 & 0.339 \\
\hline Log GDP per capita & $\begin{array}{l}0.246 \\
(0.57)\end{array}$ & $\begin{array}{l}0.112 \\
(0.28)\end{array}$ & $\begin{array}{l}0.232 \\
(0.57)\end{array}$ & $\begin{array}{l}1.405 \\
(2.34)\end{array}$ & $\begin{array}{l}0.013 \\
(0.03)\end{array}$ & $\begin{array}{l}0.193 \\
(0.45)\end{array}$ \\
\hline $\mathrm{R}^{2}$ between & 0.188 & 0.116 & 0.97 & 0.163 & 0.163 & 0.265 \\
\hline
\end{tabular}

Note: Fixed effects by country and year dummies included. ' $z$ ' statistics in parentheses. 
Table 5: Multivariate national-level effects on immigration opinion

\begin{tabular}{|c|c|c|c|c|c|c|}
\hline & (1) & (2) & (3) & (4) & (5) & (6) \\
\hline & $\begin{array}{l}\text { More/less } \\
\text { same } \\
\text { ethnic grp }\end{array}$ & $\begin{array}{l}\text { More/less } \\
\text { different } \\
\text { ethnic grp }\end{array}$ & $\begin{array}{l}\text { More/less } \\
\text { from poor } \\
\text { countries }\end{array}$ & $\begin{array}{l}\text { Immigrt } \\
\text { good for } \\
\text { economy }\end{array}$ & $\begin{array}{l}\text { Immigrt } \\
\text { enrich } \\
\text { culture }\end{array}$ & $\begin{array}{l}\text { Immigrt } \\
\text { better } \\
\text { place } \\
\end{array}$ \\
\hline Foreign born (\%) & $\begin{array}{r}-0.073 \\
(4.98)\end{array}$ & $\begin{array}{r}-0.041 \\
(2.95)\end{array}$ & $\begin{array}{r}-0.038 \\
(2.70)\end{array}$ & $\begin{array}{r}-0.038 \\
(2.04)\end{array}$ & $\begin{array}{r}-0.047 \\
(2.88)\end{array}$ & $\begin{array}{r}-0.024 \\
(1.56)\end{array}$ \\
\hline $\begin{array}{l}\text { Unemployment rate } \\
\text { (\%) }\end{array}$ & $\begin{array}{l}0.008 \\
(0.99) \\
\end{array}$ & $\begin{array}{l}0.001 \\
(0.17) \\
\end{array}$ & $\begin{array}{r}-0.000 \\
(0.03) \\
\end{array}$ & $\begin{array}{r}-0.022 \\
(2.03) \\
\end{array}$ & $\begin{array}{l}0.013 \\
(1.35) \\
\end{array}$ & $\begin{array}{r}-0.001 \\
(0.12) \\
\end{array}$ \\
\hline $\begin{array}{l}\text { Social benefits \% of } \\
\text { GDP }\end{array}$ & $\begin{array}{r}-0.036 \\
(2.52)\end{array}$ & $\begin{array}{r}-0.037 \\
(2.69)\end{array}$ & $\begin{array}{r}-0.045 \\
(3.25)\end{array}$ & $\begin{array}{r}-0.089 \\
(4.87)\end{array}$ & $\begin{array}{r}-0.023 \\
(1.46)\end{array}$ & $\begin{array}{r}-0.043 \\
(2.86)\end{array}$ \\
\hline $\mathrm{R}^{2}$ within & 0.321 & 0.294 & 0.308 & 0.495 & 0.258 & 0.382 \\
\hline No. observations & 114 & 114 & 114 & 114 & 114 & 114 \\
\hline Foreign born (\%) & $\begin{array}{r}-0.063 \\
(4.20)\end{array}$ & $\begin{array}{r}-0.038 \\
(2.49)\end{array}$ & $\begin{array}{r}-0.034 \\
(2.22)\end{array}$ & $\begin{array}{r}-0.020 \\
(1.00)\end{array}$ & $\begin{array}{r}-0.042 \\
(2.47)\end{array}$ & $\begin{array}{r}-0.017 \\
(1.03)\end{array}$ \\
\hline $\begin{array}{l}\text { Unemployment rate } \\
\text { (\%) }\end{array}$ & $\begin{array}{l}0.003 \\
(0.42)\end{array}$ & $\begin{array}{r}-0.007 \\
(0.89)\end{array}$ & $\begin{array}{r}-0.010 \\
(1.35)\end{array}$ & $\begin{array}{r}-0.037 \\
(3.71)\end{array}$ & $\begin{array}{l}0.009 \\
(1.07)\end{array}$ & $\begin{array}{r}-0.009 \\
(1.12)\end{array}$ \\
\hline $\begin{array}{l}\text { Financial deficit \% } \\
\text { of GDP }\end{array}$ & $\begin{array}{r}-0.016 \\
(2.66)\end{array}$ & $\begin{array}{r}-0.009 \\
(1.50)\end{array}$ & $\begin{array}{r}-0.010 \\
(1.65)\end{array}$ & $\begin{array}{r}-0.034 \\
(4.26)\end{array}$ & $\begin{array}{r}-0.009 \\
(1.37)\end{array}$ & $\begin{array}{r}-0.014 \\
(2.16)\end{array}$ \\
\hline $\mathrm{R}^{2}$ within & 0.326 & 0.254 & 0.264 & 0.468 & 0.256 & 0.358 \\
\hline No. observations & 114 & 114 & 114 & 114 & 114 & 114 \\
\hline Foreign born (\%) & $\begin{array}{r}-0.068 \\
(4.87) \\
\end{array}$ & $\begin{array}{r}-0.040 \\
(2.90) \\
\end{array}$ & $\begin{array}{r}-0.036 \\
(2.67) \\
\end{array}$ & $\begin{array}{r}-0.045 \\
(2.37) \\
\end{array}$ & $\begin{array}{r}-0.043 \\
(2.65) \\
\end{array}$ & $\begin{array}{r}-0.025 \\
(1.61) \\
\end{array}$ \\
\hline $\begin{array}{l}\text { Social benefits \% of } \\
\text { GDP }\end{array}$ & $\begin{array}{r}-0.024 \\
(2.01) \\
\end{array}$ & $\begin{array}{r}-0.034 \\
(2.84) \\
\end{array}$ & $\begin{array}{r}-0.041 \\
(3.45) \\
\end{array}$ & $\begin{array}{r}-0.076 \\
(6.75) \\
\end{array}$ & $\begin{array}{r}-0.012 \\
(0.83) \\
\end{array}$ & $\begin{array}{r}-0.045 \\
(3.39) \\
\end{array}$ \\
\hline $\begin{array}{l}\text { Social benefits \% } \\
\text { *fiscal impact }\end{array}$ & $\begin{array}{r}-0.048 \\
(2.65) \\
\end{array}$ & $\begin{array}{r}-0.023 \\
(1.29) \\
\end{array}$ & $\begin{array}{r}-0.042 \\
(2.38) \\
\end{array}$ & $\begin{array}{l}0.012 \\
(0.83) \\
\end{array}$ & $\begin{array}{r}-0.006 \\
(0.27) \\
\end{array}$ & $\begin{array}{l}0.004 \\
(0.19) \\
\end{array}$ \\
\hline $\mathrm{R}^{2}$ within & 0.365 & 0.307 & 0.350 & 0.472 & 0.243 & 0.382 \\
\hline No. observations & 114 & 114 & 114 & 114 & 114 & 114 \\
\hline Foreign born (\%) & $\begin{array}{r}-0.070 \\
(4.23) \\
\end{array}$ & $\begin{array}{r}-0.046 \\
(2.91) \\
\end{array}$ & $\begin{array}{r}-0.049 \\
(3.10) \\
\end{array}$ & $\begin{array}{r}-0.049 \\
(2.28) \\
\end{array}$ & $\begin{array}{r}-0.054 \\
(2.92) \\
\end{array}$ & $\begin{array}{r}-0.042 \\
(2.42) \\
\end{array}$ \\
\hline $\begin{array}{l}\text { Foreign born * share } \\
\text { non-western }\end{array}$ & $\begin{array}{l}0.001 \\
(0.03)\end{array}$ & $\begin{array}{l}0.028 \\
(0.67)\end{array}$ & $\begin{array}{l}0.060 \\
(1.40)\end{array}$ & $\begin{array}{l}0.028 \\
(0.48)\end{array}$ & $\begin{array}{l}0.059 \\
(1.18)\end{array}$ & $\begin{array}{l}0.094 \\
(2.03)\end{array}$ \\
\hline $\begin{array}{l}\text { Social benefits \% of } \\
\text { GDP }\end{array}$ & $\begin{array}{r}-0.028 \\
(2.30)\end{array}$ & $\begin{array}{r}-0.037 \\
(3.11)\end{array}$ & $\begin{array}{r}-0.048 \\
(4.03)\end{array}$ & $\begin{array}{r}-0.110 \\
(6.74)\end{array}$ & $\begin{array}{r}-0.015 \\
(1.07)\end{array}$ & $\begin{array}{r}-0.048 \\
(3.77)\end{array}$ \\
\hline $\mathrm{R}^{2}$ within & 0.313 & 0.297 & 0.323 & 0.471 & 0.254 & 0.410 \\
\hline No. observations & 114 & 114 & 114 & 114 & 114 & 114 \\
\hline
\end{tabular}

Note: Fixed effects by country and year dummies included. ' $z$ ' statistics in parentheses. 
Table 6: Effects on immigration opinion from binary variables at the first stage (coefficients *10)

\begin{tabular}{|c|c|c|c|c|c|c|}
\hline & (1) & (2) & (3) & (4) & (5) & (6) \\
\hline & $\begin{array}{l}\text { More/less } \\
\text { same } \\
\text { ethnic grp }\end{array}$ & $\begin{array}{l}\text { More/less } \\
\text { different } \\
\text { ethnic grp }\end{array}$ & $\begin{array}{l}\text { More/less } \\
\text { from poor } \\
\text { countries }\end{array}$ & $\begin{array}{l}\text { Immigrt } \\
\text { good for } \\
\text { economy }\end{array}$ & $\begin{array}{l}\text { Immigrt } \\
\text { enrich } \\
\text { culture }\end{array}$ & $\begin{array}{l}\text { Immigrt } \\
\text { better } \\
\text { place }\end{array}$ \\
\hline & \multicolumn{6}{|c|}{ First stage: dummy mid-range } \\
\hline Foreign born (\%) & $\begin{array}{r}-0.171 \\
(4.68)\end{array}$ & $\begin{array}{l}-0.117 \\
(3.22)\end{array}$ & $\begin{array}{r}-0.101 \\
(2.80)\end{array}$ & $\begin{array}{r}-0.028 \\
(0.81)\end{array}$ & $\begin{array}{r}-0.044 \\
(1.50)\end{array}$ & $\begin{array}{r}-0.018 \\
(0.62)\end{array}$ \\
\hline $\begin{array}{l}\text { Unemployment rate } \\
\text { (\%) }\end{array}$ & $\begin{array}{l}-0.019 \\
(0.89)\end{array}$ & $\begin{array}{l}0.003 \\
(0.16)\end{array}$ & $\begin{array}{r}-0.001 \\
(0.08)\end{array}$ & $\begin{array}{l}-0.059 \\
(2.84)\end{array}$ & $\begin{array}{r}-0.003 \\
(0.19)\end{array}$ & $\begin{array}{r}-0.010 \\
(0.58)\end{array}$ \\
\hline $\begin{array}{l}\text { Social benefits \% of } \\
\text { GDP }\end{array}$ & $\begin{array}{r}-0.070 \\
(1.95)\end{array}$ & $\begin{array}{r}-0.076 \\
(2.13)\end{array}$ & $\begin{array}{r}-0.077 \\
(2.19)\end{array}$ & $\begin{array}{r}-0.139 \\
(4.01)\end{array}$ & $\begin{array}{r}-0.018 \\
(0.64)\end{array}$ & $\begin{array}{r}-0.062 \\
(2.14)\end{array}$ \\
\hline $\mathrm{R}^{2}$ within & 0.266 & 0.230 & 0.451 & 0.451 & 0.144 & 0.277 \\
\hline \multirow[t]{2}{*}{ No. observations } & 114 & 114 & 114 & 114 & 114 & 114 \\
\hline & \multicolumn{6}{|c|}{ First stage: dummy high } \\
\hline Foreign born (\%) & $\begin{array}{l}-0.138 \\
(5.01)\end{array}$ & $\begin{array}{r}-0.047 \\
(2.39)\end{array}$ & $\begin{array}{r}-0.041 \\
(2.05) \\
\end{array}$ & $\begin{array}{r}-0.009 \\
(0.38)\end{array}$ & $\begin{array}{r}-0.027 \\
(1.11)\end{array}$ & $\begin{array}{r}-0.001 \\
(0.06)\end{array}$ \\
\hline $\begin{array}{l}\text { Unemployment rate } \\
\text { (\%) }\end{array}$ & $\begin{array}{l}0.011 \\
(0.68)\end{array}$ & $\begin{array}{r}-0.006 \\
(0.48)\end{array}$ & $\begin{array}{r}-0.006 \\
(0.59)\end{array}$ & $\begin{array}{r}-0.033 \\
(2.31)\end{array}$ & $\begin{array}{l}0.003 \\
(0.26)\end{array}$ & $\begin{array}{r}-0.001 \\
(0.13)\end{array}$ \\
\hline $\begin{array}{l}\text { Social benefits \% of } \\
\text { GDP }\end{array}$ & $\begin{array}{l}-0.057 \\
(2.12)\end{array}$ & $\begin{array}{r}-0.036 \\
(1.85)\end{array}$ & $\begin{array}{r}-0.042 \\
(2.15)\end{array}$ & $\begin{array}{r}-0.090 \\
(3.56)\end{array}$ & $\begin{array}{r}-0.013 \\
(0.56)\end{array}$ & $\begin{array}{r}-0.030 \\
(1.56)\end{array}$ \\
\hline $\mathrm{R}^{2}$ within & 0.266 & 0.183 & 0.236 & 0.444 & 0.221 & 0.110 \\
\hline \multirow[t]{2}{*}{ No. observations } & 114 & 114 & 114 & 114 & 114 & 114 \\
\hline & \multicolumn{6}{|c|}{ First stage: dummy low } \\
\hline Foreign born (\%) & $\begin{array}{r}-0.044 \\
(2.66) \\
\end{array}$ & $\begin{array}{r}-0.030 \\
(1.25) \\
\end{array}$ & $\begin{array}{r}-0.018 \\
(0.71) \\
\end{array}$ & $\begin{array}{r}-0.068 \\
(2.14) \\
\end{array}$ & $\begin{array}{r}-0.070 \\
(3.11)\end{array}$ & $\begin{array}{r}-0.050 \\
(1.76)\end{array}$ \\
\hline $\begin{array}{l}\text { Unemployment rate } \\
(\%)\end{array}$ & $\begin{array}{r}-0.001 \\
(0.08)\end{array}$ & $\begin{array}{r}-0.002 \\
(0.12)\end{array}$ & $\begin{array}{r}-0.010 \\
(0.65)\end{array}$ & $\begin{array}{r}-0.022 \\
(1.34)\end{array}$ & $\begin{array}{l}0.018 \\
(1.36)\end{array}$ & $\begin{array}{l}0.007 \\
(0.40)\end{array}$ \\
\hline $\begin{array}{l}\text { Social benefits \% of } \\
\text { GDP }\end{array}$ & $\begin{array}{l}-0.046 \\
(2.85)\end{array}$ & $\begin{array}{r}-0.071 \\
(3.03)\end{array}$ & $\begin{array}{r}-0.097 \\
(3.98)\end{array}$ & $\begin{array}{l}-0.124 \\
(4.52)\end{array}$ & $\begin{array}{r}-0.035 \\
(1.57)\end{array}$ & $\begin{array}{r}-0.056 \\
(2.00)\end{array}$ \\
\hline $\mathrm{R}^{2}$ within & 0.334 & 0.326 & 0.459 & 0.457 & 0.296 & 0.163 \\
\hline No. observations & 114 & 114 & 114 & 114 & 114 & 114 \\
\hline
\end{tabular}

Note: Fixed effects by country and year dummies included. ' $z$ ' statistics in parentheses. 
Table 7: National-level effects by education group

\begin{tabular}{|c|c|c|c|c|c|c|}
\hline & (1) & (2) & (3) & (4) & $(5)$ & (6) \\
\hline & $\begin{array}{l}\text { More/less } \\
\text { same } \\
\text { ethnic grp }\end{array}$ & $\begin{array}{l}\text { More/less } \\
\text { different } \\
\text { ethnic grp }\end{array}$ & $\begin{array}{l}\text { More/less } \\
\text { from poor } \\
\text { countries }\end{array}$ & $\begin{array}{l}\text { Immigrt } \\
\text { good for } \\
\text { economy }\end{array}$ & $\begin{array}{l}\text { Immigrt } \\
\text { enrich } \\
\text { culture }\end{array}$ & $\begin{array}{l}\text { Immigrt } \\
\text { better } \\
\text { place }\end{array}$ \\
\hline & \multicolumn{6}{|c|}{ First stage: high education only } \\
\hline Foreign born (\%) & $\begin{array}{r}-0.075 \\
(4.24)\end{array}$ & $\begin{array}{r}-0.043 \\
(2.60)\end{array}$ & $\begin{array}{r}-0.030 \\
(1.73)\end{array}$ & $\begin{array}{r}-0.013 \\
(0.57)\end{array}$ & $\begin{array}{r}-0.006 \\
(0.30)\end{array}$ & $\begin{array}{l}0.016 \\
(0.78)\end{array}$ \\
\hline $\begin{array}{l}\text { Unemployment rate } \\
\text { (\%) }\end{array}$ & $\begin{array}{l}0.016 \\
(1.62)\end{array}$ & $\begin{array}{l}0.015 \\
(1.54)\end{array}$ & $\begin{array}{l}0.011 \\
(1.03)\end{array}$ & $\begin{array}{r}-0.000 \\
(0.02)\end{array}$ & $\begin{array}{l}0.013 \\
(1.04)\end{array}$ & $\begin{array}{l}0.004 \\
(0.33)\end{array}$ \\
\hline $\begin{array}{l}\text { Social benefits \% of } \\
\text { GDP }\end{array}$ & $\begin{array}{r}-0.028 \\
(1.70) \\
\end{array}$ & $\begin{array}{r}-0.035 \\
(3.05) \\
\end{array}$ & $\begin{array}{r}-0.039 \\
(2.31) \\
\end{array}$ & $\begin{array}{r}-0.089 \\
(3.94) \\
\end{array}$ & $\begin{array}{r}-0.008 \\
(0.37) \\
\end{array}$ & $\begin{array}{r}-0.040 \\
(2.04) \\
\end{array}$ \\
\hline $\mathrm{R}^{2}$ within & 0.228 & 0.171 & 0.149 & 0.276 & 0.088 & 0.237 \\
\hline \multirow[t]{2}{*}{ No. observations } & 114 & 114 & 114 & 114 & 114 & 114 \\
\hline & \multicolumn{6}{|c|}{ First stage: middle education only } \\
\hline Foreign born (\%) & $\begin{array}{r}-0.075 \\
(5.15) \\
\end{array}$ & $\begin{array}{r}-0.044 \\
(3.05) \\
\end{array}$ & $\begin{array}{r}-0.041 \\
(2.84) \\
\end{array}$ & $\begin{array}{r}-0.047 \\
(2.32) \\
\end{array}$ & $\begin{array}{r}-0.060 \\
(3.48) \\
\end{array}$ & $\begin{array}{r}-0.038 \\
(2.35) \\
\end{array}$ \\
\hline $\begin{array}{l}\text { Unemployment rate } \\
\text { (\%) }\end{array}$ & $\begin{array}{l}0.008 \\
(1.03)\end{array}$ & $\begin{array}{l}0.001 \\
(0.13)\end{array}$ & $\begin{array}{r}-0.001 \\
(0.18)\end{array}$ & $\begin{array}{r}-0.024 \\
(2.01)\end{array}$ & $\begin{array}{l}0.016 \\
(1.53)\end{array}$ & $\begin{array}{l}0.002 \\
(0.18)\end{array}$ \\
\hline $\begin{array}{l}\text { Financial deficit \% } \\
\text { of GDP }\end{array}$ & $\begin{array}{r}-0.036 \\
(2.53) \\
\end{array}$ & $\begin{array}{r}-0.035 \\
(2.44) \\
\end{array}$ & $\begin{array}{r}-0.038 \\
(2.70) \\
\end{array}$ & $\begin{array}{r}-0.094 \\
(4.76) \\
\end{array}$ & $\begin{array}{r}-0.026 \\
(1.54) \\
\end{array}$ & $\begin{array}{r}-0.044 \\
(2.77) \\
\end{array}$ \\
\hline $\mathrm{R}^{2}$ within & 0.339 & 0.288 & 0.270 & 0.497 & 0.275 & 0.346 \\
\hline No. observations & 114 & 114 & 114 & 114 & 114 & 114 \\
\hline & \multicolumn{6}{|c|}{ First stage: low education only } \\
\hline Foreign born (\%) & $\begin{array}{r}-0.066 \\
(4.06) \\
\end{array}$ & $\begin{array}{r}-0.040 \\
(2.47) \\
\end{array}$ & $\begin{array}{r}-0.039 \\
(2.37) \\
\end{array}$ & $\begin{array}{r}-0.040 \\
(2.02) \\
\end{array}$ & $\begin{array}{r}-0.050 \\
(2.66) \\
\end{array}$ & $\begin{array}{r}-0.030 \\
(1.75) \\
\end{array}$ \\
\hline $\begin{array}{l}\text { Unemployment rate } \\
\text { (\%) }\end{array}$ & $\begin{array}{l}0.003 \\
(0.31)\end{array}$ & $\begin{array}{r}-0.007 \\
(0.69)\end{array}$ & $\begin{array}{r}-0.008 \\
(0.80)\end{array}$ & $\begin{array}{r}-0.036 \\
(3.15)\end{array}$ & $\begin{array}{l}0.007 \\
(0.67)\end{array}$ & $\begin{array}{r}-0.011 \\
(1.10)\end{array}$ \\
\hline $\begin{array}{l}\text { Social benefits \% of } \\
\text { GDP }\end{array}$ & $\begin{array}{l}-0.041 \\
(2.54)\end{array}$ & $\begin{array}{r}-0.037 \\
(2.33)\end{array}$ & $\begin{array}{r}-0.052 \\
(3.27)\end{array}$ & $\begin{array}{r}-0.086 \\
(4.47)\end{array}$ & $\begin{array}{l}0.034 \\
(1.87)\end{array}$ & $\begin{array}{r}-0.050 \\
(3.00)\end{array}$ \\
\hline $\mathrm{R}^{2}$ within & 0.303 & 0.291 & 0.329 & 0.519 & 0.257 & 0.422 \\
\hline No. observations & 114 & 114 & 114 & 114 & 114 & 114 \\
\hline $\begin{array}{l}\text { F-test }(p) \text { for edu- } \\
\text { cation differences }\end{array}$ & $\begin{array}{l}2.89 \\
0.01\end{array}$ & $\begin{array}{l}1.62 \\
0.14\end{array}$ & $\begin{array}{l}1.69 \\
0.12\end{array}$ & $\begin{array}{l}3.34 \\
0.03\end{array}$ & $\begin{array}{l}1.99 \\
0.07\end{array}$ & $\begin{array}{l}1.84 \\
0.09\end{array}$ \\
\hline
\end{tabular}

Note: Fixed effects by country and year dummies included. ' $z$ ' statistics in parentheses. 
Table 8: Tests for equality of coefficients

\begin{tabular}{|c|c|c|c|c|c|c|}
\hline & (1) & (2) & (3) & (4) & (5) & (6) \\
\hline & $\begin{array}{l}\text { More/less } \\
\text { same } \\
\text { ethnic grp }\end{array}$ & $\begin{array}{l}\text { More/less } \\
\text { different } \\
\text { ethnic grp }\end{array}$ & $\begin{array}{l}\text { More/less } \\
\text { from poor } \\
\text { countries }\end{array}$ & $\begin{array}{l}\text { Immigrt } \\
\text { good for } \\
\text { economy }\end{array}$ & $\begin{array}{l}\text { Immigrt } \\
\text { enrich } \\
\text { culture }\end{array}$ & $\begin{array}{l}\text { Immigrt } \\
\text { better } \\
\text { place }\end{array}$ \\
\hline & \multicolumn{6}{|c|}{ Three education groups: high, middle, low } \\
\hline$F(6,169)$ & 2.89 & 1.62 & 1.69 & 3.34 & 1.99 & 1.84 \\
\hline \multirow[t]{2}{*}{ P-value } & 0.01 & 0.14 & 0.12 & 0.00 & 0.07 & 0.09 \\
\hline & \multicolumn{6}{|c|}{ Young (under 40) and old (40+) } \\
\hline$F(3,172)$ & 0.51 & 0.99 & 0.83 & 1.11 & 0.75 & 0.88 \\
\hline \multirow[t]{2}{*}{ P-value } & 0.68 & 0.40 & 0.48 & 0.34 & 0.53 & 0.45 \\
\hline & \multicolumn{6}{|c|}{ Male and female } \\
\hline$F(3,172)$ & 0.04 & 0.12 & 0.08 & 0.39 & 0.45 & 0.31 \\
\hline \multirow[t]{2}{*}{ P-value } & 0.99 & 0.95 & 0.97 & 0.76 & 0.72 & 0.82 \\
\hline & \multicolumn{6}{|c|}{ Labour force participants and non-participants } \\
\hline$F(3,172)$ & 0.15 & 0.14 & 0.27 & 0.16 & 0.41 & 0.14 \\
\hline \multirow[t]{2}{*}{ P-value } & 0.93 & 0.94 & 0.85 & 0.92 & 0.75 & 0.93 \\
\hline & \multicolumn{6}{|c|}{ Ethnic minority and non-ethnic minority } \\
\hline$F(3,172)$ & 0.85 & 1.11 & 0.59 & 0.28 & 0.65 & 0.31 \\
\hline P-value & 0.47 & 0.34 & 0.62 & 0.84 & 0.58 & 0.82 \\
\hline
\end{tabular}

Note: These tests are based on regressions in analogous to those in Table 7 and in Table A2. They are obtained from pooled regressions which include interactions to allow the coefficients to differ across groups. The F-test is for the joint significance of the interaction terms.

Table 9: Country-by-country tests for interactions with country dummies. Dependent variable: Immigration good for the economy.

\begin{tabular}{|l|r|r|l|r|r|}
\hline Country & F-stat & $\mathrm{p}$-value & Country & F-stat & p-value \\
\hline Belgium & 0.38 & 0.765 & Greece & 2.43 & 0.070 \\
\hline Switzerland & 0.23 & 0.878 & Hungary & 1.25 & 0.299 \\
\hline Czech Rep. & 3.97 & 0.011 & Ireland & 2.47 & 0.062 \\
\hline Germany & 1.69 & 0.176 & Netherlands & 1.40 & 0.250 \\
\hline Denmark & 0.33 & 0.806 & Norway & 0.70 & 0.555 \\
\hline Estonia & 2.28 & 0.085 & Poland & 0.65 & 0.582 \\
\hline Spain & 0.79 & 0.501 & Portugal & 0.51 & 0.680 \\
\hline Finland & 0.09 & 0.963 & Sweden & 0.18 & 0.908 \\
\hline France & 0.81 & 0.493 & Slovenia & 0.62 & 0.603 \\
\hline Great Britain & 0.76 & 0.521 & Slovakia & 1.45 & 0.233 \\
\hline
\end{tabular}

Note: These tests are obtained from regressions that are analogous to those in Table A3 but where the country excluded in Table A3 has been added and each of the variables is interacted with a dummy for that country. The F-test is for the joint significance of the interaction terms. 
Table 10: Year effects on attitudes linked to immigration opinion

\begin{tabular}{|c|c|c|c|c|c|c|}
\hline & (1) & (2) & (3) & (4) & (5) & (6) \\
\hline & $\begin{array}{l}\text { Trust in } \\
\text { people }\end{array}$ & $\begin{array}{l}\text { Important } \\
\text { to be safe }\end{array}$ & $\begin{array}{l}\text { Traditions } \\
\text { important }\end{array}$ & $\begin{array}{l}\text { Trust in } \\
\text { politicians }\end{array}$ & $\begin{array}{l}\text { Satisfied } \\
\text { with govt }\end{array}$ & $\begin{array}{l}\text { Left-right } \\
\text { scale }\end{array}$ \\
\hline 2002 & $\begin{array}{r}-0.124 \\
(2.25)\end{array}$ & $\begin{array}{r}-0.099 \\
(3.25)\end{array}$ & $\begin{array}{r}-0.010 \\
(0.35)\end{array}$ & $\begin{array}{r}0.205 \\
(1.60)\end{array}$ & $\begin{array}{r}-0.100 \\
(0.42)\end{array}$ & $\begin{array}{r}-0.055 \\
(1.01)\end{array}$ \\
\hline 2004 & $\begin{array}{r}-0.105 \\
(1.96) \\
\end{array}$ & $\begin{array}{r}-0.053 \\
(1.78)\end{array}$ & $\begin{array}{r}-0.018 \\
(0.63) \\
\end{array}$ & $\begin{array}{r}-0.072 \\
(0.58) \\
\end{array}$ & $\begin{array}{r}-0.265 \\
(1.19) \\
\end{array}$ & $\begin{array}{r}-0.039 \\
(0.76)\end{array}$ \\
\hline 2008 & $\begin{array}{r}-0.033 \\
(0.62)\end{array}$ & $\begin{array}{r}-0.025 \\
(0.85)\end{array}$ & $\begin{array}{l}0.019 \\
(0.68)\end{array}$ & $\begin{array}{r}-0.071 \\
(0.57)\end{array}$ & $\begin{array}{r}-0.374 \\
(1.68)\end{array}$ & $\begin{array}{r}-0.048 \\
(0.92)\end{array}$ \\
\hline 2010 & $\begin{array}{r}-0.023 \\
(0.43)\end{array}$ & $\begin{array}{r}-0.069 \\
(2.35)\end{array}$ & $\begin{array}{r}-0.021 \\
(0.74)\end{array}$ & $\begin{array}{r}-0.227 \\
(1.84)\end{array}$ & $\begin{array}{r}-0.517 \\
(2.32)\end{array}$ & $\begin{array}{l}0.018 \\
(0.34)\end{array}$ \\
\hline 2012 & $\begin{array}{l}0.035 \\
(0.64)\end{array}$ & $\begin{array}{r}-0.130 \\
(4.28)\end{array}$ & $\begin{array}{l}0.012 \\
(0.57)\end{array}$ & $\begin{array}{r}-0.099 \\
(0.78)\end{array}$ & $\begin{array}{l}-0.301 \\
(1.32)\end{array}$ & $\begin{array}{l}0.022 \\
(0.41)\end{array}$ \\
\hline $\mathrm{R}^{2}$ within & 0.125 & 0.219 & 0.103 & 0.128 & 0.073 & 0.046 \\
\hline$F$ (p-value) & 0.034 & 0.000 & 0.081 & 0.030 & 0.238 & 0.509 \\
\hline Observations & 114 & 114 & 114 & 114 & 113 & 114 \\
\hline
\end{tabular}

Note: Fixed effects by country; ' $z$ ' statistics in parentheses. Responses to the question 'satisfied with the government' are missing for Ireland in 2002.

Table 11: Residual correlations between immigration opinion and other attitudes

\begin{tabular}{|l|r|r|r|r|r|r|}
\hline & \multicolumn{1}{|l|}{$(1)$} & \multicolumn{1}{l}{ (2) } & \multicolumn{1}{l|}{$(3)$} & $(4)$ & \multicolumn{1}{l|}{$(5)$} & $(6)$ \\
\hline & $\begin{array}{l}\text { Trust in } \\
\text { people }\end{array}$ & $\begin{array}{l}\text { Important } \\
\text { to be safe }\end{array}$ & $\begin{array}{l}\text { Traditions } \\
\text { important }\end{array}$ & $\begin{array}{l}\text { Trust in } \\
\text { politicians }\end{array}$ & $\begin{array}{l}\text { Satisfied } \\
\text { with govt }\end{array}$ & $\begin{array}{l}\text { Left-right } \\
\text { scale }\end{array}$ \\
\hline $\begin{array}{l}\text { More/less same } \\
\text { ethnic group }\end{array}$ & $0.367^{*}$ & -0.009 & -0.009 & 0.034 & 0.141 & 0.296 \\
\hline $\begin{array}{l}\text { More/less different } \\
\text { ethnic group }\end{array}$ & $0.390^{*}$ & 0.122 & -0.032 & $0.313^{*}$ & $0.275^{*}$ & $0.318^{*}$ \\
\hline $\begin{array}{l}\text { More/less from poor } \\
\text { countries }\end{array}$ & $0.406^{*}$ & 0.119 & -0.073 & $0.329^{*}$ & $0.327^{*}$ & $0.347^{*}$ \\
\hline $\begin{array}{l}\text { Immigrants } \\
\text { good for economy }\end{array}$ & $0.408^{*}$ & -0.034 & -0.237 & $0.620^{*}$ & $0.639^{*}$ & $0.316^{*}$ \\
\hline $\begin{array}{l}\text { Immigrants enrich } \\
\text { Culture }\end{array}$ & $0.421^{*}$ & 0.029 & -0.027 & $0.255^{*}$ & 0.211 & 0.240 \\
\hline $\begin{array}{l}\text { Immigrants make } \\
\text { better place }\end{array}$ & $0.428^{*}$ & 0.078 & 0.089 & $0.509^{*}$ & $0.455^{*}$ & $0.348^{*}$ \\
\hline
\end{tabular}

Note: Correlation coefficients between the country/year residuals from regressions in Table 3 and those in Table 10. * denotes significant at the 1 percent level. 
Table 12: The effect of economic variables on a range of attitudes.

\begin{tabular}{|c|c|c|c|c|c|c|}
\hline & (1) & (2) & (3) & (4) & (5) & (6) \\
\hline & $\begin{array}{l}\text { Trust in } \\
\text { people }\end{array}$ & $\begin{array}{l}\text { Important } \\
\text { to be safe }\end{array}$ & $\begin{array}{l}\text { Traditions } \\
\text { important }\end{array}$ & $\begin{array}{l}\text { Trust } \\
\text { politicians }\end{array}$ & $\begin{array}{l}\text { Satisfied } \\
\text { with govt. }\end{array}$ & $\begin{array}{l}\text { Left-right } \\
\text { scale }\end{array}$ \\
\hline Foreign born (\%) & $\begin{array}{r}-0.024 \\
(1.81) \\
\end{array}$ & $\begin{array}{r}-0.022 \\
(3.09) \\
\end{array}$ & $\begin{array}{r}-0.009 \\
(1.50) \\
\end{array}$ & $\begin{array}{l}0.043 \\
(1.65) \\
\end{array}$ & $\begin{array}{l}0.005 \\
(0.10) \\
\end{array}$ & $\begin{array}{r}0.010 \\
(0.82) \\
\end{array}$ \\
\hline $\begin{array}{l}\text { Unemployment rate } \\
\text { (\%) }\end{array}$ & $\begin{array}{r}-0.002 \\
(0.30) \\
\end{array}$ & $\begin{array}{c}0.004 \\
(1.12) \\
\end{array}$ & $\begin{array}{c}0.003 \\
(0.82) \\
\end{array}$ & $\begin{array}{r}-0.030 \\
(1.99) \\
\end{array}$ & $\begin{array}{r}-0.059 \\
(2.28) \\
\end{array}$ & $\begin{array}{c}0.002 \\
(0.29)\end{array}$ \\
\hline $\begin{array}{l}\text { Social benefits \% of } \\
\text { GDP }\end{array}$ & $\begin{array}{r}-0.018 \\
(1.42) \\
\end{array}$ & $\begin{array}{l}0.007 \\
(0.95) \\
\end{array}$ & $\begin{array}{l}0.021 \\
(3.29) \\
\end{array}$ & $\begin{array}{r}-0.110 \\
(4.31) \\
\end{array}$ & $\begin{array}{r}-0.230 \\
(5.26) \\
\end{array}$ & $\begin{array}{r}-0.040 \\
(3.23) \\
\end{array}$ \\
\hline $\mathrm{R}^{2}$ within & 0.202 & 0.312 & 0.271 & 0.418 & 0.465 & 0.175 \\
\hline No. observations & 114 & 114 & 114 & 114 & 114 & 114 \\
\hline Foreign born (\%) & $\begin{array}{r}-0.019 \\
(1.41)\end{array}$ & $\begin{array}{r}-0.027 \\
(3.73)\end{array}$ & $\begin{array}{r}-0.017 \\
(2.65)\end{array}$ & $\begin{array}{l}0.058 \\
(2.05)\end{array}$ & $\begin{array}{l}0.040 \\
(0.81)\end{array}$ & $\begin{array}{r}0.020 \\
(1.54)\end{array}$ \\
\hline $\begin{array}{l}\text { Unemployment rate } \\
\text { (\%) }\end{array}$ & $\begin{array}{r}-0.005 \\
(0.73)\end{array}$ & $\begin{array}{l}0.004 \\
(1.12)\end{array}$ & $\begin{array}{l}0.052 \\
(1.60)\end{array}$ & $\begin{array}{r}-0.053 \\
(3.64)\end{array}$ & $\begin{array}{r}-0.105 \\
(4.21)\end{array}$ & $\begin{array}{r}-0.004 \\
(0.57)\end{array}$ \\
\hline $\begin{array}{l}\text { Financial deficit \% } \\
\text { of GDP }\end{array}$ & $\begin{array}{r}-0.008 \\
(1.47) \\
\end{array}$ & $\begin{array}{l}0.007 \\
(2.57) \\
\end{array}$ & $\begin{array}{l}0.012 \\
(4.75) \\
\end{array}$ & $\begin{array}{l}0.033 \\
(2.85) \\
\end{array}$ & $\begin{array}{r}-0.063 \\
(3.17) \\
\end{array}$ & $\begin{array}{r}-0.018 \\
(3.38) \\
\end{array}$ \\
\hline $\mathrm{R}^{2}$ within & 0.205 & 0.354 & 0.350 & 0.353 & 0.366 & 0.180 \\
\hline No. observations & 114 & 114 & 114 & 114 & 113 & 114 \\
\hline
\end{tabular}

Note: Fixed effects by country and year dummies included. ' $z$ ' statistics in parentheses. Responses to the question 'satisfied with the government' are missing for Ireland in 2002. 
Table 13: The effects on immigration opinion of other attitudes and traits

\begin{tabular}{|c|c|c|c|c|c|c|}
\hline & (1) & (2) & (3) & (4) & (5) & (6) \\
\hline & $\begin{array}{l}\text { More/less } \\
\text { same } \\
\text { ethnic grp }\end{array}$ & $\begin{array}{l}\text { More/less } \\
\text { different } \\
\text { ethnic grp }\end{array}$ & $\begin{array}{l}\text { More/less } \\
\text { from poor } \\
\text { countries }\end{array}$ & $\begin{array}{l}\text { Immigrt } \\
\text { good for } \\
\text { economy }\end{array}$ & $\begin{array}{l}\text { Immigrt } \\
\text { enrich } \\
\text { culture }\end{array}$ & $\begin{array}{l}\text { Immigrt } \\
\text { better } \\
\text { place }\end{array}$ \\
\hline Foreign born (\%) & $\begin{array}{r}-0.073 \\
(5.14)\end{array}$ & $\begin{array}{r}-0.042 \\
(3.13)\end{array}$ & $\begin{array}{r}-0.041 \\
(3.02)\end{array}$ & $\begin{array}{r}-0.049 \\
(3.15)\end{array}$ & $\begin{array}{r}-0.051 \\
(3.39)\end{array}$ & $\begin{array}{r}-0.025 \\
(1.89)\end{array}$ \\
\hline $\begin{array}{l}\text { Unemployment rate } \\
\text { (\%) }\end{array}$ & $\begin{array}{l}0.008 \\
(1.05)\end{array}$ & $\begin{array}{l}0.001 \\
(0.19)\end{array}$ & $\begin{array}{r}-0.000 \\
(0.01)\end{array}$ & $\begin{array}{r}-0.021 \\
(2.38)\end{array}$ & $\begin{array}{l}0.013 \\
(1.55)\end{array}$ & $\begin{array}{r}-0.001 \\
(0.12)\end{array}$ \\
\hline $\begin{array}{l}\text { Social benefits \% of } \\
\text { GDP }\end{array}$ & $\begin{array}{l}-0.036 \\
(2.61)\end{array}$ & $\begin{array}{r}-0.037 \\
(2.86)\end{array}$ & $\begin{array}{r}-0.047 \\
(3.59)\end{array}$ & $\begin{array}{r}-0.100 \\
(6.53)\end{array}$ & $\begin{array}{r}-0.027 \\
(1.83)\end{array}$ & $\begin{array}{r}-0.044 \\
(3.38)\end{array}$ \\
\hline $\begin{array}{l}\text { Trust in people } \\
\text { (residual) }\end{array}$ & $\begin{array}{l}0.266 \\
(2.25)\end{array}$ & $\begin{array}{l}0.226 \\
(2.03)\end{array}$ & $\begin{array}{l}0.251 \\
(2.23)\end{array}$ & $\begin{array}{l}0.336 \\
(2.58)\end{array}$ & $\begin{array}{l}0.373 \\
(2.98)\end{array}$ & $\begin{array}{l}0.296 \\
(2.61)\end{array}$ \\
\hline $\begin{array}{l}\text { Satisfied with govt. } \\
\text { (residual) }\end{array}$ & $\begin{array}{l}0.065 \\
(0.98)\end{array}$ & $\begin{array}{r}-0.112 \\
(1.77)\end{array}$ & $\begin{array}{r}-0.077 \\
(1.21)\end{array}$ & $\begin{array}{r}-0.007 \\
(0.10)\end{array}$ & $\begin{array}{r}-0.074 \\
(1.05)\end{array}$ & $\begin{array}{l}-0.065 \\
(1.02)\end{array}$ \\
\hline $\begin{array}{l}\text { Trust in politicians } \\
\text { (residual) }\end{array}$ & $\begin{array}{l}-0.169 \\
(1.51)\end{array}$ & $\begin{array}{l}0.251 \\
(2.36)\end{array}$ & $\begin{array}{l}0.179 \\
(1.67)\end{array}$ & $\begin{array}{l}0.287 \\
(2.32)\end{array}$ & $\begin{array}{l}0.252 \\
(2.12)\end{array}$ & $\begin{array}{l}0.312 \\
(2.95)\end{array}$ \\
\hline $\begin{array}{l}\text { Left-right scale } \\
\text { (residual) }\end{array}$ & $\begin{array}{l}0.273 \\
(2.19)\end{array}$ & $\begin{array}{l}0.246 \\
(2.09)\end{array}$ & $\begin{array}{l}0.265 \\
(2.23)\end{array}$ & $\begin{array}{l}0.200 \\
(1.45)\end{array}$ & $\begin{array}{l}0.227 \\
(1.72)\end{array}$ & $\begin{array}{l}0.318 \\
(2.02)\end{array}$ \\
\hline $\mathrm{R}^{2}$ within & 0.405 & 0.424 & 0.426 & 0.683 & 0.445 & 0.580 \\
\hline No. observations & 113 & 113 & 113 & 113 & 113 & 113 \\
\hline
\end{tabular}

Note: Note: Fixed effects by country and year dummies included. ' $z$ ' statistics in parentheses. Responses to the question 'satisfied with the government' are missing for Ireland in 2002; otherwise the coefficients and standard errors on the first three variables would be identical with those in the first panel of Table 5. 
Figure 1: Standardized time trends: Immigrants Good for the Economy
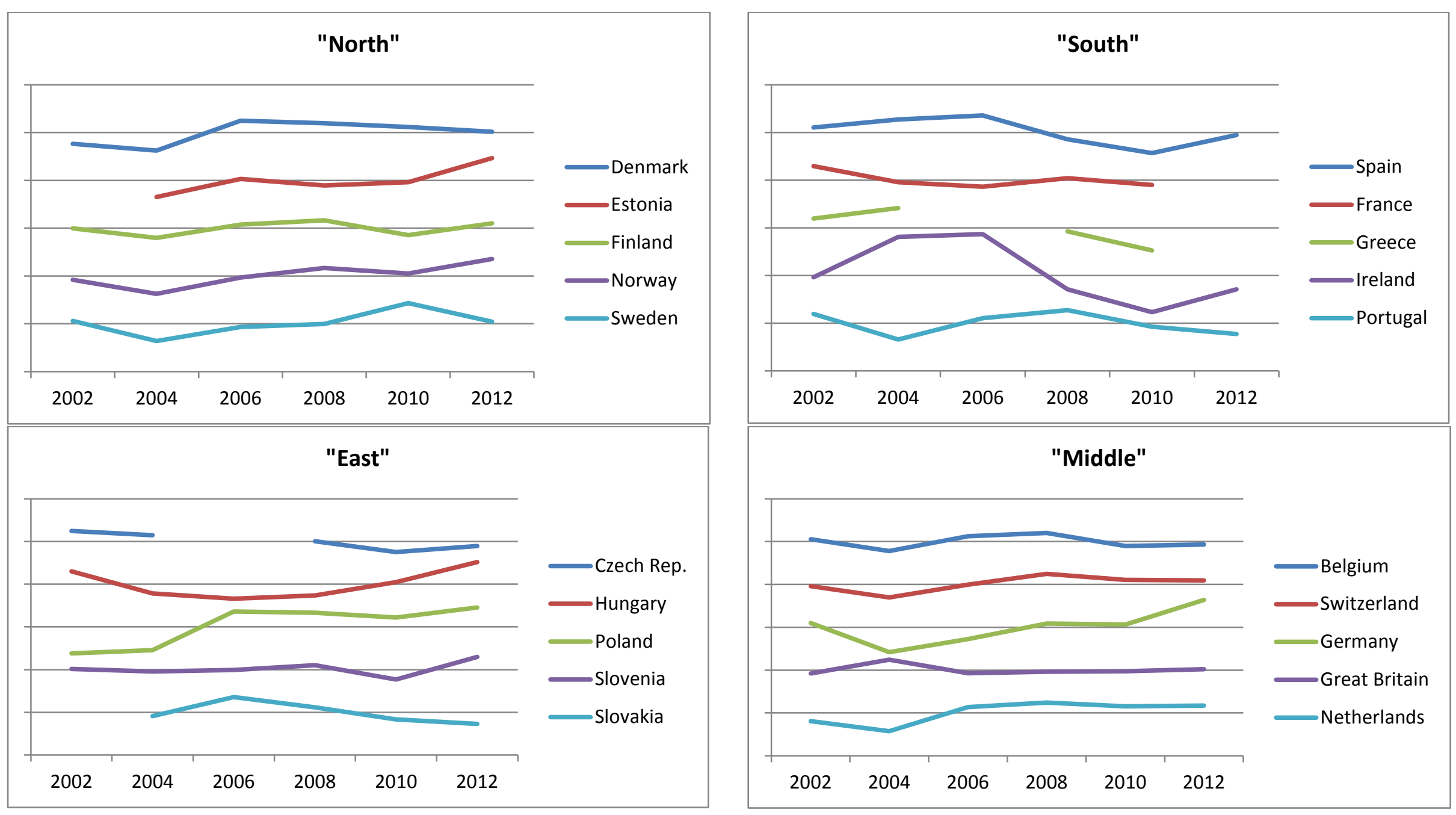


\section{Appendix}

Table A1: Individual-level regressions by country on ESS waves 1-6 (2002-12). Dependent variable: Immigration good for the economy (scale 0-10).

\begin{tabular}{|c|c|c|c|c|c|c|c|c|c|c|}
\hline & Belgium & $\begin{array}{l}\text { Switzer- } \\
\text { land }\end{array}$ & $\begin{array}{l}\text { Czech } \\
\text { Republic }\end{array}$ & Germany & Denmark & Estonia & Spain & Finland & France & \begin{tabular}{|l|} 
Great \\
Britain \\
\end{tabular} \\
\hline Born in country & $\begin{array}{r}-0.721 \\
(10.36)\end{array}$ & $\begin{array}{r}-0.544 \\
(5.57)\end{array}$ & $\begin{array}{r}-0.330 \\
(1.91)\end{array}$ & $\begin{array}{r}-0.652 \\
(8.83)\end{array}$ & $\begin{array}{r}-0.608 \\
(4.07)\end{array}$ & $\begin{array}{r}-0.450 \\
(3.70)\end{array}$ & $\begin{array}{l}-1.523 \\
(16.82)\end{array}$ & $\begin{array}{r}-0.234 \\
(2.10)\end{array}$ & $\begin{array}{l}-1.028 \\
(12.73)\end{array}$ & $\begin{array}{r}-1.187 \\
(12.79)\end{array}$ \\
\hline $\begin{array}{l}\text { Labour force } \\
\text { participant }\end{array}$ & $\begin{array}{r}-0.205 \\
(2.46)\end{array}$ & $\begin{array}{l}0.023 \\
(0.52)\end{array}$ & $\begin{array}{l}0.009 \\
(0.17)\end{array}$ & $\begin{array}{r}-0.229 \\
(3.08)\end{array}$ & $\begin{array}{r}-0.114 \\
(1.41)\end{array}$ & $\begin{array}{r}-0.099 \\
(1.85)\end{array}$ & $\begin{array}{r}-0.154 \\
(2.78)\end{array}$ & $\begin{array}{r}-0.099 \\
(1.58)\end{array}$ & $\begin{array}{r}-0.140 \\
(1.72)\end{array}$ & $\begin{array}{r}-0.201 \\
(4.44)\end{array}$ \\
\hline High education & $\begin{array}{r}1.305 \\
(10.01)\end{array}$ & $\begin{array}{r}1.106 \\
(11.81)\end{array}$ & $\begin{array}{l}1.034 \\
(5.80)\end{array}$ & $\begin{array}{r}1.122 \\
(16.75)\end{array}$ & $\begin{array}{r}1.157 \\
(15.38)\end{array}$ & $\begin{array}{l}0.766 \\
(9.52)\end{array}$ & $\begin{array}{l}0.978 \\
(5.98)\end{array}$ & $\begin{array}{r}1.076 \\
(18.00)\end{array}$ & $\begin{array}{r}1.593 \\
(13.67)\end{array}$ & $\begin{array}{r}1.069 \\
(12.32)\end{array}$ \\
\hline Mid-level education & $\begin{array}{l}0.393 \\
(5.55)\end{array}$ & $\begin{array}{l}0.470 \\
(5.34)\end{array}$ & $\begin{array}{l}0.148 \\
(1.53)\end{array}$ & $\begin{array}{l}0.307 \\
(5.66)\end{array}$ & $\begin{array}{l}0.475 \\
(6.71)\end{array}$ & $\begin{array}{l}0.176 \\
(6.38)\end{array}$ & $\begin{array}{r}0.686 \\
(14.32)\end{array}$ & $\begin{array}{l}0.336 \\
(3.83)\end{array}$ & $\begin{array}{r}0.507 \\
(26.06)\end{array}$ & $\begin{array}{l}0.402 \\
(5.01)\end{array}$ \\
\hline between & 0.003 & 0.357 & 0.682 & 0.714 & 0.284 & 0.015 & 0.124 & 0.304 & 0.073 & 0.040 \\
\hline overall & 0.084 & 0.073 & 0.020 & 0.061 & 0.081 & 0.066 & 0.091 & 0.582 & 0.115 & 0.099 \\
\hline Country/years & 6 & 6 & 5 & 6 & 6 & 5 & 6 & 6 & 5 & 6 \\
\hline Observations & 10367 & 10284 & 8934 & 16309 & 8745 & 7751 & 10593 & 11804 & 8886 & 12333 \\
\hline
\end{tabular}

Note: Fixed effects by year. ' $z$ ' statistics in parentheses computed from standard errors. 
Table A1 Contd.: Individual regressions by country on ESS waves 1-6 (2002-12). Dependent variable: Immigration good for the economy (scale 0-10).

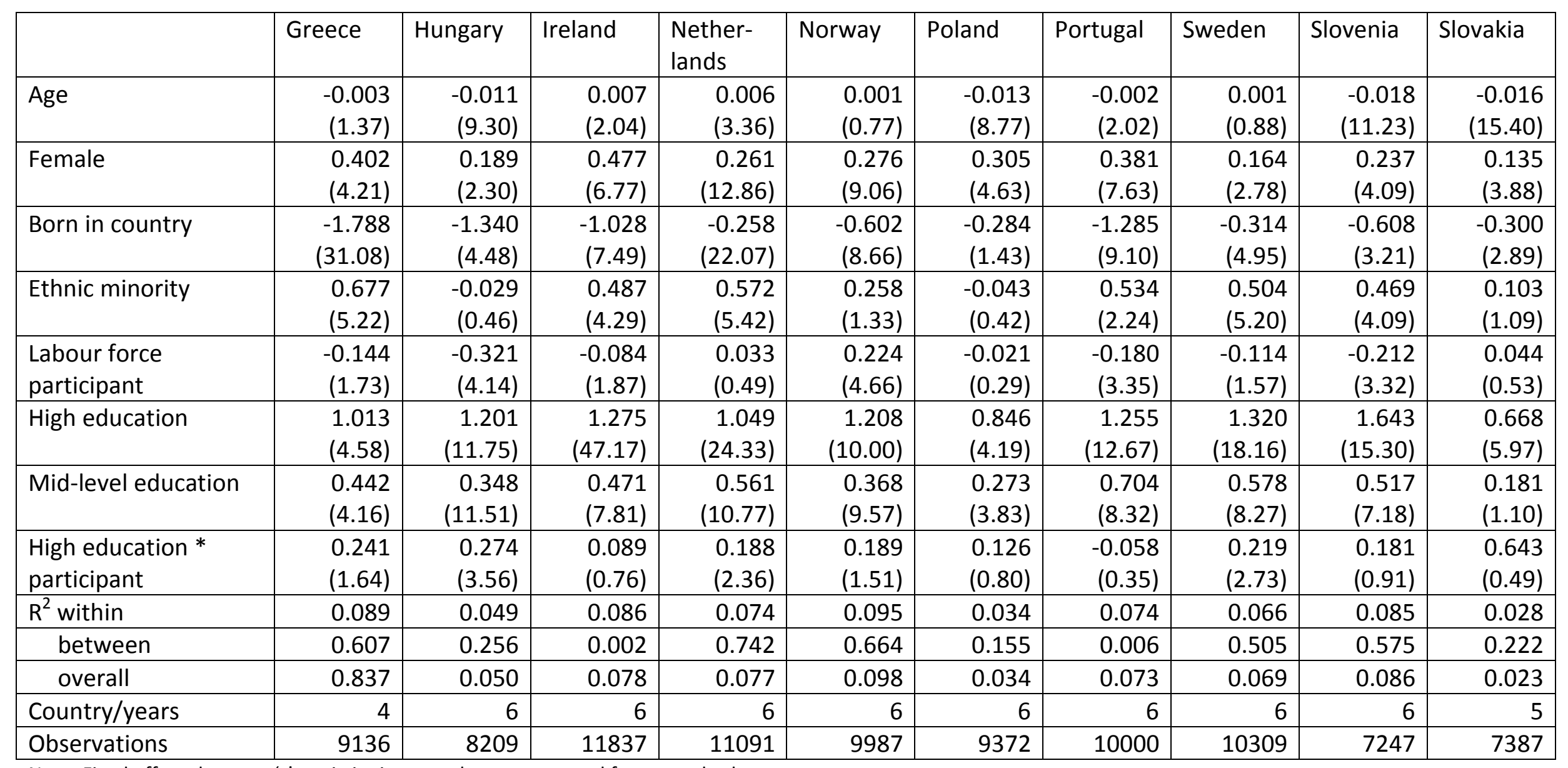

Note: Fixed effects by year. ' $z$ ' statistics in parentheses computed from standard errors. 
Table A2: National effects by age, sex and labour force status

\begin{tabular}{|c|c|c|c|c|c|c|}
\hline & (1) & $(2)$ & (3) & (4) & (5) & (6) \\
\hline & $\begin{array}{l}\text { More/less } \\
\text { same } \\
\text { ethnic grp }\end{array}$ & $\begin{array}{l}\text { More/less } \\
\text { different } \\
\text { ethnic grp }\end{array}$ & $\begin{array}{l}\text { More/less } \\
\text { from poor } \\
\text { countries }\end{array}$ & $\begin{array}{l}\text { Immigrt } \\
\text { good for } \\
\text { economy }\end{array}$ & $\begin{array}{l}\text { Immigrt } \\
\text { enrich } \\
\text { culture }\end{array}$ & $\begin{array}{l}\text { Immigrt } \\
\text { better } \\
\text { place }\end{array}$ \\
\hline & \multicolumn{6}{|c|}{ First stage: age under 40 only } \\
\hline Foreign born (\%) & $\begin{array}{r}-0.075 \\
(4.24)\end{array}$ & $\begin{array}{r}-0.043 \\
(2.60)\end{array}$ & $\begin{array}{r}-0.030 \\
(1.73)\end{array}$ & $\begin{array}{r}-0.013 \\
(0.57)\end{array}$ & $\begin{array}{r}-0.006 \\
(0.30)\end{array}$ & $\begin{array}{l}0.016 \\
(0.78)\end{array}$ \\
\hline $\begin{array}{l}\text { Unemployment rate } \\
\text { (\%) }\end{array}$ & $\begin{array}{l}0.016 \\
(1.62)\end{array}$ & $\begin{array}{l}0.015 \\
(1.54)\end{array}$ & $\begin{array}{l}0.011 \\
(1.03)\end{array}$ & $\begin{array}{r}-0.000 \\
(0.02)\end{array}$ & $\begin{array}{l}0.013 \\
(1.04)\end{array}$ & $\begin{array}{l}0.004 \\
(0.33)\end{array}$ \\
\hline $\begin{array}{l}\text { Social benefits \% of } \\
\text { GDP }\end{array}$ & $\begin{array}{l}-0.028 \\
(1.70)\end{array}$ & $\begin{array}{r}-0.035 \\
(3.05)\end{array}$ & $\begin{array}{r}-0.039 \\
(2.31) \\
\end{array}$ & $\begin{array}{r}-0.089 \\
(3.94) \\
\end{array}$ & $\begin{array}{r}-0.008 \\
(0.37) \\
\end{array}$ & $\begin{array}{r}-0.040 \\
(2.04) \\
\end{array}$ \\
\hline $\mathrm{R}^{2}$ within & 0.228 & 0.171 & 0.149 & 0.276 & 0.088 & 0.237 \\
\hline \multirow[t]{2}{*}{ No. observations } & 114 & 114 & 114 & 114 & 114 & 114 \\
\hline & \multicolumn{6}{|c|}{ First stage: age $40+$ only } \\
\hline Foreign born (\%) & $\begin{array}{l}-0.075 \\
(5.15) \\
\end{array}$ & $\begin{array}{r}-0.044 \\
(3.05) \\
\end{array}$ & \begin{tabular}{|r|}
-0.041 \\
$(2.84)$ \\
\end{tabular} & $\begin{array}{r}-0.047 \\
(2.32) \\
\end{array}$ & $\begin{array}{r}-0.060 \\
(3.48) \\
\end{array}$ & $\begin{array}{r}-0.038 \\
(2.35) \\
\end{array}$ \\
\hline $\begin{array}{l}\text { Unemployment rate } \\
\text { (\%) }\end{array}$ & $\begin{array}{l}0.008 \\
(1.03)\end{array}$ & $\begin{array}{l}0.001 \\
(0.13)\end{array}$ & $\begin{array}{r}-0.001 \\
(0.18)\end{array}$ & $\begin{array}{r}-0.024 \\
(2.01)\end{array}$ & $\begin{array}{l}0.016 \\
(1.53)\end{array}$ & $\begin{array}{l}0.002 \\
(0.18)\end{array}$ \\
\hline $\begin{array}{l}\text { Social benefits \% of } \\
\text { GDP }\end{array}$ & $\begin{array}{r}-0.036 \\
(2.53)\end{array}$ & $\begin{array}{r}-0.035 \\
(2.44)\end{array}$ & $\begin{array}{r}-0.038 \\
(2.70)\end{array}$ & $\begin{array}{r}-0.094 \\
(4.76)\end{array}$ & $\begin{array}{r}-0.026 \\
(1.54)\end{array}$ & $\begin{array}{r}-0.044 \\
(2.77)\end{array}$ \\
\hline $\mathrm{R}^{2}$ within & 0.339 & 0.288 & 0.270 & 0.497 & 0.275 & 0.346 \\
\hline \multirow[t]{2}{*}{ No. observations } & 114 & 114 & 114 & 114 & 114 & 114 \\
\hline & \multicolumn{6}{|c|}{ First stage: male only } \\
\hline Foreign born (\%) & $\begin{array}{r}-0.066 \\
(4.06) \\
\end{array}$ & $\begin{array}{r}-0.040 \\
(2.47) \\
\end{array}$ & $\begin{array}{r}-0.039 \\
(2.37) \\
\end{array}$ & $\begin{array}{r}-0.040 \\
(2.02) \\
\end{array}$ & $\begin{array}{r}-0.050 \\
(2.66) \\
\end{array}$ & $\begin{array}{r}-0.030 \\
(1.75) \\
\end{array}$ \\
\hline $\begin{array}{l}\text { Unemployment rate } \\
\text { (\%) }\end{array}$ & $\begin{array}{l}0.003 \\
(0.31) \\
\end{array}$ & $\begin{array}{r}-0.007 \\
(0.69) \\
\end{array}$ & $\begin{array}{r}-0.008 \\
(0.80) \\
\end{array}$ & $\begin{array}{r}-0.036 \\
(3.15) \\
\end{array}$ & $\begin{array}{l}0.007 \\
(0.67) \\
\end{array}$ & $\begin{array}{r}-0.011 \\
(1.10) \\
\end{array}$ \\
\hline $\begin{array}{l}\text { Social benefits \% of } \\
\text { GDP }\end{array}$ & $\begin{array}{r}-0.041 \\
(2.54) \\
\end{array}$ & $\begin{array}{r}-0.037 \\
(2.33) \\
\end{array}$ & $\begin{array}{r}-0.052 \\
(3.27) \\
\end{array}$ & $\begin{array}{r}-0.086 \\
(4.47) \\
\end{array}$ & $\begin{array}{l}0.034 \\
(1.87) \\
\end{array}$ & $\begin{array}{r}-0.050 \\
(3.00) \\
\end{array}$ \\
\hline $\mathrm{R}^{2}$ within & 0.303 & 0.291 & 0.329 & 0.519 & 0.257 & 0.422 \\
\hline \multirow[t]{2}{*}{ No. observations } & 114 & 114 & 114 & 114 & 114 & 114 \\
\hline & \multicolumn{6}{|c|}{ First stage: female only } \\
\hline Foreign born (\%) & $\begin{array}{r}-0.071 \\
(5.07)\end{array}$ & $\begin{array}{r}-0.041 \\
(3.12)\end{array}$ & $\begin{array}{r}-0.038 \\
(2.81)\end{array}$ & $\begin{array}{r}-0.036 \\
(1.98)\end{array}$ & $\begin{array}{r}-0.058 \\
(3.53)\end{array}$ & $\begin{array}{r}-0.030 \\
(1.84)\end{array}$ \\
\hline $\begin{array}{l}\text { Unemployment rate } \\
\text { (\%) }\end{array}$ & $\begin{array}{l}0.007 \\
(0.93)\end{array}$ & $\begin{array}{l}0.004 \\
(0.52)\end{array}$ & $\begin{array}{l}0.002 \\
(0.26)\end{array}$ & $\begin{array}{r}-0.016 \\
(1.51)\end{array}$ & $\begin{array}{l}0.017 \\
(1.80)\end{array}$ & $\begin{array}{l}0.004 \\
(0.47)\end{array}$ \\
\hline $\begin{array}{l}\text { Social benefits \% of } \\
\text { GDP }\end{array}$ & $\begin{array}{r}-0.038 \\
(2.78)\end{array}$ & $\begin{array}{r}-0.042 \\
(3.23)\end{array}$ & $\begin{array}{r}-0.049 \\
(3.70)\end{array}$ & $\begin{array}{r}-0.088 \\
(4.95)\end{array}$ & $\begin{array}{c}0.025 \\
(1.54)\end{array}$ & $\begin{array}{r}-0.046 \\
(2.91)\end{array}$ \\
\hline $\mathrm{R}^{2}$ within & 0.355 & 0.348 & 0.358 & 0.484 & 0.317 & 0.406 \\
\hline No. observations & 114 & 114 & 114 & 114 & 114 & 114 \\
\hline
\end{tabular}

Note: Fixed effects by country and year dummies included. ' $z$ ' statistics in parentheses. 
Table A2 continued

\begin{tabular}{|c|c|c|c|c|c|c|}
\hline & (1) & (2) & (3) & (4) & (5) & (6) \\
\hline & $\begin{array}{l}\text { More/less } \\
\text { same } \\
\text { ethnic grp }\end{array}$ & $\begin{array}{l}\text { More/less } \\
\text { different } \\
\text { ethnic grp }\end{array}$ & $\begin{array}{l}\text { More/less } \\
\text { from poor } \\
\text { countries }\end{array}$ & $\begin{array}{l}\text { Immigrt } \\
\text { good for } \\
\text { economy }\end{array}$ & $\begin{array}{l}\text { Immigrt } \\
\text { enrich } \\
\text { culture }\end{array}$ & $\begin{array}{l}\text { Immigrt } \\
\text { better } \\
\text { place }\end{array}$ \\
\hline & \multicolumn{6}{|c|}{ First Stage: labour force participants } \\
\hline Foreign born (\%) & $\begin{array}{r}-0.070 \\
(4.91)\end{array}$ & $\begin{array}{r}-0.040 \\
(2.76)\end{array}$ & $\begin{array}{r}-0.039 \\
(2.66)\end{array}$ & $\begin{array}{r}-0.035 \\
(1.86)\end{array}$ & $\begin{array}{r}-0.040 \\
(2.36)\end{array}$ & $\begin{array}{r}-0.019 \\
(1.17)\end{array}$ \\
\hline $\begin{array}{l}\text { Unemployment rate } \\
\text { (\%) }\end{array}$ & $\begin{array}{l}0.007 \\
(0.80)\end{array}$ & $\begin{array}{l}0.002 \\
(0.22)\end{array}$ & $\begin{array}{r}-0.001 \\
(0.20)\end{array}$ & $\begin{array}{r}-0.017 \\
(1.58)\end{array}$ & $\begin{array}{l}0.014 \\
(1.45)\end{array}$ & $\begin{array}{l}0.001 \\
(0.14)\end{array}$ \\
\hline $\begin{array}{l}\text { Social benefits \% of } \\
\text { GDP }\end{array}$ & $\begin{array}{r}-0.032 \\
(2.24)\end{array}$ & $\begin{array}{r}-0.033 \\
(2.33)\end{array}$ & $\begin{array}{r}-0.038 \\
(2.60)\end{array}$ & $\begin{array}{r}-0.091 \\
(4.81)\end{array}$ & $\begin{array}{r}-0.018 \\
(1.09)\end{array}$ & $\begin{array}{r}-0.047 \\
(2.96)\end{array}$ \\
\hline $\mathrm{R}^{2}$ within & 0.291 & 0.230 & 0.252 & 0.466 & 0.224 & 0.340 \\
\hline \multirow[t]{2}{*}{ No. observations } & 114 & 114 & 114 & 114 & 114 & 114 \\
\hline & \multicolumn{6}{|c|}{ First stage: non-participants } \\
\hline Foreign born (\%) & $\begin{array}{r}-0.071 \\
(4.38)\end{array}$ & $\begin{array}{r}-0.041 \\
(2.77)\end{array}$ & $\begin{array}{r}-0.036 \\
(2.49)\end{array}$ & $\begin{array}{r}-0.038 \\
(1.92)\end{array}$ & $\begin{array}{r}-0.053 \\
(2.99)\end{array}$ & $\begin{array}{r}-0.028 \\
(1.70)\end{array}$ \\
\hline $\begin{array}{l}\text { Unemployment rate } \\
\text { (\%) }\end{array}$ & $\begin{array}{l}0.011 \\
(1.12)\end{array}$ & $\begin{array}{l}0.000 \\
(0.03)\end{array}$ & $\begin{array}{l}0.001 \\
(0.17)\end{array}$ & $\begin{array}{r}-0.028 \\
(2.42)\end{array}$ & $\begin{array}{l}0.010 \\
(0.94)\end{array}$ & $\begin{array}{r}-0.005 \\
(0.46)\end{array}$ \\
\hline $\begin{array}{l}\text { Social benefits \% of } \\
\text { GDP }\end{array}$ & $\begin{array}{l}-0.046 \\
(2.90)\end{array}$ & $\begin{array}{r}-0.042 \\
(2.92)\end{array}$ & $\begin{array}{r}-0.055 \\
(3.91)\end{array}$ & $\begin{array}{r}-0.087 \\
(4.46)\end{array}$ & $\begin{array}{r}-0.030 \\
(1.71)\end{array}$ & $\begin{array}{r}-0.039 \\
(2.37)\end{array}$ \\
\hline $\mathrm{R}^{2}$ within & 0.320 & 0.330 & 0.355 & 0.481 & 0.261 & 0.364 \\
\hline \multirow[t]{2}{*}{ No. observations } & 114 & 114 & 114 & 114 & 114 & 114 \\
\hline & \multicolumn{6}{|c|}{ First stage: ethnic minority } \\
\hline Foreign born (\%) & $\begin{array}{r}-0.084 \\
(3.44)\end{array}$ & $\begin{array}{r}-0.065 \\
(2.52)\end{array}$ & $\begin{array}{r}-0.064 \\
(2.70)\end{array}$ & $\begin{array}{r}-0.033 \\
(0.97)\end{array}$ & $\begin{array}{r}-0.026 \\
(0.71)\end{array}$ & $\begin{array}{r}-0.045 \\
(1.50)\end{array}$ \\
\hline $\begin{array}{l}\text { Unemployment rate } \\
\text { (\%) }\end{array}$ & $\begin{array}{r}-0.014 \\
(0.96)\end{array}$ & $\begin{array}{r}-0.021 \\
(1.45)\end{array}$ & $\begin{array}{r}-0.001 \\
(0.06)\end{array}$ & $\begin{array}{r}-0.039 \\
(1.96)\end{array}$ & $\begin{array}{l}0.008 \\
(0.36)\end{array}$ & $\begin{array}{l}0.013 \\
(0.73)\end{array}$ \\
\hline $\begin{array}{l}\text { Social benefits \% of } \\
\text { GDP }\end{array}$ & $\begin{array}{r}-0.006 \\
(0.26)\end{array}$ & $\begin{array}{r}-0.006 \\
(0.23)\end{array}$ & $\begin{array}{r}-0.023 \\
(1.01)\end{array}$ & $\begin{array}{r}-0.059 \\
(1.77)\end{array}$ & $\begin{array}{r}-0.066 \\
(1.85)\end{array}$ & $\begin{array}{r}-0.050 \\
(1.71)\end{array}$ \\
\hline $\mathrm{R}^{2}$ within & 0.224 & 0.183 & 0.215 & 0.206 & 0.115 & 0.159 \\
\hline No. observations & 114 & 114 & 114 & 114 & 114 & 114 \\
\hline & \multicolumn{6}{|c|}{ First stage: non-ethnic minority } \\
\hline Foreign born (\%) & $\begin{array}{r}-0.072 \\
(4.87) \\
\end{array}$ & $\begin{array}{r}-0.039 \\
(2.79) \\
\end{array}$ & $\begin{array}{r}-0.036 \\
(2.54) \\
\end{array}$ & $\begin{array}{r}-0.038 \\
(2.02) \\
\end{array}$ & $\begin{array}{r}-0.047 \\
(2.87) \\
\end{array}$ & $\begin{array}{r}-0.021 \\
(1.37) \\
\end{array}$ \\
\hline $\begin{array}{l}\text { Unemployment rate } \\
\text { (\%) }\end{array}$ & $\begin{array}{l}0.010 \\
(1.13)\end{array}$ & $\begin{array}{l}0.002 \\
(0.28)\end{array}$ & $\begin{array}{l}0.000 \\
(0.00)\end{array}$ & $\begin{array}{r}-0.022 \\
(1.94)\end{array}$ & $\begin{array}{l}0.013 \\
(1.32)\end{array}$ & $\begin{array}{r}-0.002 \\
(0.18)\end{array}$ \\
\hline $\begin{array}{l}\text { Social benefits \% of } \\
\text { GDP }\end{array}$ & $\begin{array}{r}-0.039 \\
(2.70)\end{array}$ & $\begin{array}{r}-0.041 \\
(2.96)\end{array}$ & $\begin{array}{r}-0.048 \\
(3.42)\end{array}$ & $\begin{array}{r}-0.091 \\
(4.87)\end{array}$ & $\begin{array}{r}-0.025 \\
(1.56)\end{array}$ & $\begin{array}{r}-0.047 \\
(3.06)\end{array}$ \\
\hline $\mathrm{R}^{2}$ within & 0.321 & 0.303 & 0.312 & 0.494 & 0.265 & 0.398 \\
\hline No. observations & 114 & 114 & 114 & 114 & 114 & 114 \\
\hline
\end{tabular}

Note: Fixed effects by country and year dummies included. ' $z$ ' statistics in parentheses. 
Table A3: Country-level regressions omitting each country in succession. Dependent variable: Immigration good for the economy (fixed effects from first stage regressions).

\begin{tabular}{|c|c|c|c|c|c|c|c|c|c|c|}
\hline Country omitted & Belgium & $\begin{array}{l}\text { Switzer- } \\
\text { land }\end{array}$ & $\begin{array}{l}\text { Czech } \\
\text { Republic }\end{array}$ & Germany & Denmark & Estonia & Spain & Finland & France & $\begin{array}{l}\text { Great } \\
\text { Britain }\end{array}$ \\
\hline Foreign born (\%) & $\begin{array}{r}-0.037 \\
(1.93)\end{array}$ & $\begin{array}{r}-0.036 \\
(1.88)\end{array}$ & $\begin{array}{r}-0.041 \\
(2.29)\end{array}$ & $\begin{array}{r}-0.040 \\
(2.10)\end{array}$ & $\begin{array}{r}-0.036 \\
(1.88)\end{array}$ & $\begin{array}{r}-0.022 \\
(1.11)\end{array}$ & $\begin{array}{r}-0.042 \\
(2.12)\end{array}$ & $\begin{array}{r}-0.037 \\
(1.95)\end{array}$ & $\begin{array}{r}-0.041 \\
(2.15)\end{array}$ & $\begin{array}{r}-0.039 \\
(2.04)\end{array}$ \\
\hline $\begin{array}{l}\text { Unemployment rate } \\
(\%)\end{array}$ & $\begin{array}{r}-0.023 \\
(2.06) \\
\end{array}$ & $\begin{array}{r}-0.023 \\
(2.04) \\
\end{array}$ & $\begin{array}{r}-0.023 \\
(2.21) \\
\end{array}$ & $\begin{array}{r}-0.019 \\
(1.71) \\
\end{array}$ & $\begin{array}{r}-0.023 \\
(2.00) \\
\end{array}$ & $\begin{array}{r}-0.028 \\
(2.50) \\
\end{array}$ & $\begin{array}{r}-0.028 \\
(2.22) \\
\end{array}$ & $\begin{array}{r}-0.021 \\
(1.80) \\
\end{array}$ & $\begin{array}{r}-0.022 \\
(1.97) \\
\end{array}$ & $\begin{array}{r}-0.021 \\
(1.90) \\
\end{array}$ \\
\hline $\begin{array}{l}\text { Social benefits \% of } \\
\text { GDP }\end{array}$ & $\begin{array}{r}-0.088 \\
(4.64)\end{array}$ & $\begin{array}{r}-0.089 \\
(4.60)\end{array}$ & $\begin{array}{r}-0.095 \\
(5.36)\end{array}$ & $\begin{array}{r}-0.092 \\
(4.89)\end{array}$ & $\begin{array}{r}-0.087 \\
(4.65)\end{array}$ & $\begin{array}{r}-0.093 \\
(5.07)\end{array}$ & $\begin{array}{r}-0.088 \\
(4.70)\end{array}$ & $\begin{array}{r}-0.092 \\
(4.66)\end{array}$ & $\begin{array}{r}-0.088 \\
(4.78)\end{array}$ & $\begin{array}{r}-0.090 \\
(4.80)\end{array}$ \\
\hline $\mathrm{R}^{2}$ within & 0.495 & 0.490 & 0.550 & 0.475 & 0.490 & 0.514 & 0.491 & 0.491 & 0.503 & 508 \\
\hline$F$ test ( $p$-value) & 0.765 & 0.878 & 0.011 & 0.176 & 0.806 & 0.085 & 0.501 & 0.963 & 0.493 & 0.521 \\
\hline No. observations & 108 & 108 & 109 & 108 & 108 & 109 & 108 & 108 & 109 & 108 \\
\hline Country omitted & Greece & Hungary & Ireland & $\begin{array}{l}\text { Nether- } \\
\text { lands }\end{array}$ & Norway & Poland & Portugal & Sweden & Slovenia & Slovakia \\
\hline Foreign born (\%) & $\begin{array}{r}-0.054 \\
(2.79) \\
\end{array}$ & $\begin{array}{r}-0.040 \\
(2.11) \\
\end{array}$ & $\begin{array}{r}-0.034 \\
(1.86) \\
\end{array}$ & $\begin{array}{r}-0.029 \\
(1.55) \\
\end{array}$ & $\begin{array}{r}-0.042 \\
(2.14) \\
\end{array}$ & $\begin{array}{r}-0.037 \\
(1.96) \\
\end{array}$ & $\begin{array}{r}-0.037 \\
(1.90) \\
\end{array}$ & $\begin{array}{r}-0.039 \\
(2.05) \\
\end{array}$ & $\begin{array}{r}-0.043 \\
(1.97) \\
\end{array}$ & $\begin{array}{r}-0.035 \\
(1.77) \\
\end{array}$ \\
\hline $\begin{array}{l}\text { Unemployment rate } \\
(\%)\end{array}$ & $\begin{array}{r}-0.024 \\
(2.22) \\
\end{array}$ & $\begin{array}{r}-0.025 \\
(2.15) \\
\end{array}$ & $\begin{array}{r}-0.019 \\
(1.84) \\
\end{array}$ & $\begin{array}{r}-0.020 \\
(1.85) \\
\end{array}$ & $\begin{array}{r}-0.020 \\
(1.73) \\
\end{array}$ & $\begin{array}{r}-0.018 \\
(1.45) \\
\end{array}$ & $\begin{array}{r}-0.21 \\
(1.77) \\
\end{array}$ & $\begin{array}{r}-0.022 \\
(1.97) \\
\end{array}$ & $\begin{array}{r}-0.022 \\
(1.96) \\
\end{array}$ & $\begin{array}{r}-0.025 \\
(2.12) \\
\end{array}$ \\
\hline $\begin{array}{l}\text { Social benefits \% of } \\
\text { GDP }\end{array}$ & $\begin{array}{r}-0.076 \\
(3.95)\end{array}$ & $\begin{array}{r}-0.079 \\
(3.99)\end{array}$ & $\begin{array}{r}-0.082 \\
(4.54)\end{array}$ & $\begin{array}{r}-0.097 \\
(5.20)\end{array}$ & $\begin{array}{r}-0.093 \\
(4.69)\end{array}$ & $\begin{array}{r}-0.093 \\
(5.00)\end{array}$ & $\begin{array}{r}-0.092 \\
(4.91)\end{array}$ & $\begin{array}{r}-0.090 \\
(4.60)\end{array}$ & $\begin{array}{r}-0.090 \\
(4.77)\end{array}$ & $\begin{array}{r}-0.087 \\
(4.70)\end{array}$ \\
\hline $\mathrm{R}^{2}$ within & 0.511 & 0.483 & 0.471 & 0.511 & 0.490 & 0.450 & 0.500 & 0.504 & 0.502 & 507 \\
\hline$F$ test ( $p$-value) & 0.070 & 0.299 & 0.067 & 0.250 & 0.555 & 0.582 & 0.680 & 0.908 & 0.603 & 0.233 \\
\hline No. observations & 110 & 108 & 108 & 108 & 108 & 108 & 108 & 108 & 108 & 109 \\
\hline
\end{tabular}

Note: Fixed effects by country and year dummies included. ' $z$ ' statistics in parentheses. 


\section{Data sources and definitions}

\section{ESS data}

The first five waves are from the cumulative dataset for the first five rounds 2002-2010 and the second edition of round 6 (2012). These are obtained from Norwegian Social Science Data Services, Norway - Data Archive and distributor of ESS data. Opinion and attitudinal variables and defined in the text; the personal characteristics used as explanatory variables are as follows.

\begin{tabular}{|l|l|}
\hline Variable & ESS definition \\
\hline Age & AGEA: Age calculated in years. \\
\hline Sex & GNDR: Sex. \\
\hline Born in country & BRNCNTR: Born in country. \\
\hline Ethnic minority & BLGETMG: Belong to an ethnic minority group. \\
\hline Labour force participant & $\begin{array}{l}\text { PDWRK: Paid work in last 7 days, or UEMPLA: Unemployed and } \\
\text { actively looking for a job in last 7 days. }\end{array}$ \\
\hline Education & $\begin{array}{l}\text { EDULVLA: Highest level of education completed. Divided into } \\
\text { three education groups: High (Tertiary education completed-ISCED } \\
\text { 5-6), Middle (Upper secondary or post-secondary non-tertiary-ISCED } \\
\text { 3-4), Low (All other-ISCED 0-2 and not classified). }\end{array}$ \\
\hline
\end{tabular}

\section{National-level variables}

\begin{tabular}{|l|l|}
\hline Data Series & Source/definition \\
\hline $\begin{array}{l}\text { Foreign born percentage } \\
\text { of population. }\end{array}$ & $\begin{array}{l}\text { OECD, International Migration Outlook 2013, Table A.4: Stocks of } \\
\text { foreign-born population in OECD countries and the Russian } \\
\text { Federation. }\end{array}$ \\
\hline $\begin{array}{l}\text { Unemployment } \\
\text { percentage }\end{array}$ & $\begin{array}{l}\text { OECD: Harmonised unemployment rate all persons (average of } \\
\text { monthly rates). }\end{array}$ \\
\hline $\begin{array}{l}\text { Social benefits } \\
\text { percentage of GDP }\end{array}$ & $\begin{array}{l}\text { OECD: Social benefits and social transfers in kind (series } \\
\text { D62_D63PS13S) - Percentage of GDP. }\end{array}$ \\
\hline $\begin{array}{l}\text { Financial deficit } \\
\text { percentage of GDP }\end{array}$ & $\begin{array}{l}\text { OECD: Net lending/net borrowing - General government - } \\
\text { Percentage of GDP (series B9S13S). }\end{array}$ \\
\hline GDP per capita & $\begin{array}{l}\text { OECD: GDP Per head, US \$, constant prices, constant PPPs, OECD } \\
\text { base year. }\end{array}$ \\
\hline Fiscal impact & $\begin{array}{l}\text { OECD International Migration Outlook, 2013, Table 3 A4: Ratio of } \\
\text { fiscal benefits to contributions; immigrants minus natives. }\end{array}$ \\
\hline $\begin{array}{l}\text { Non-western immigrant } \\
\text { share of all foreign-born }\end{array}$ & $\begin{array}{l}\text { OECD: Migration Database: Immigrants by citizenship and age. } \\
\text { For 2001; non-western = Africa, Asia and Latin America. }\end{array}$ \\
\hline
\end{tabular}

